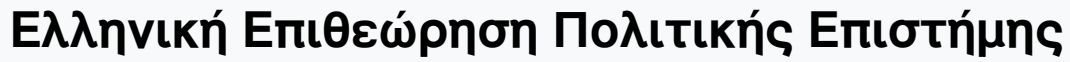

Tóp. 41 (2013)

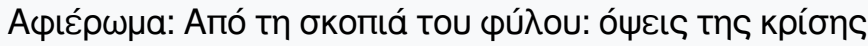

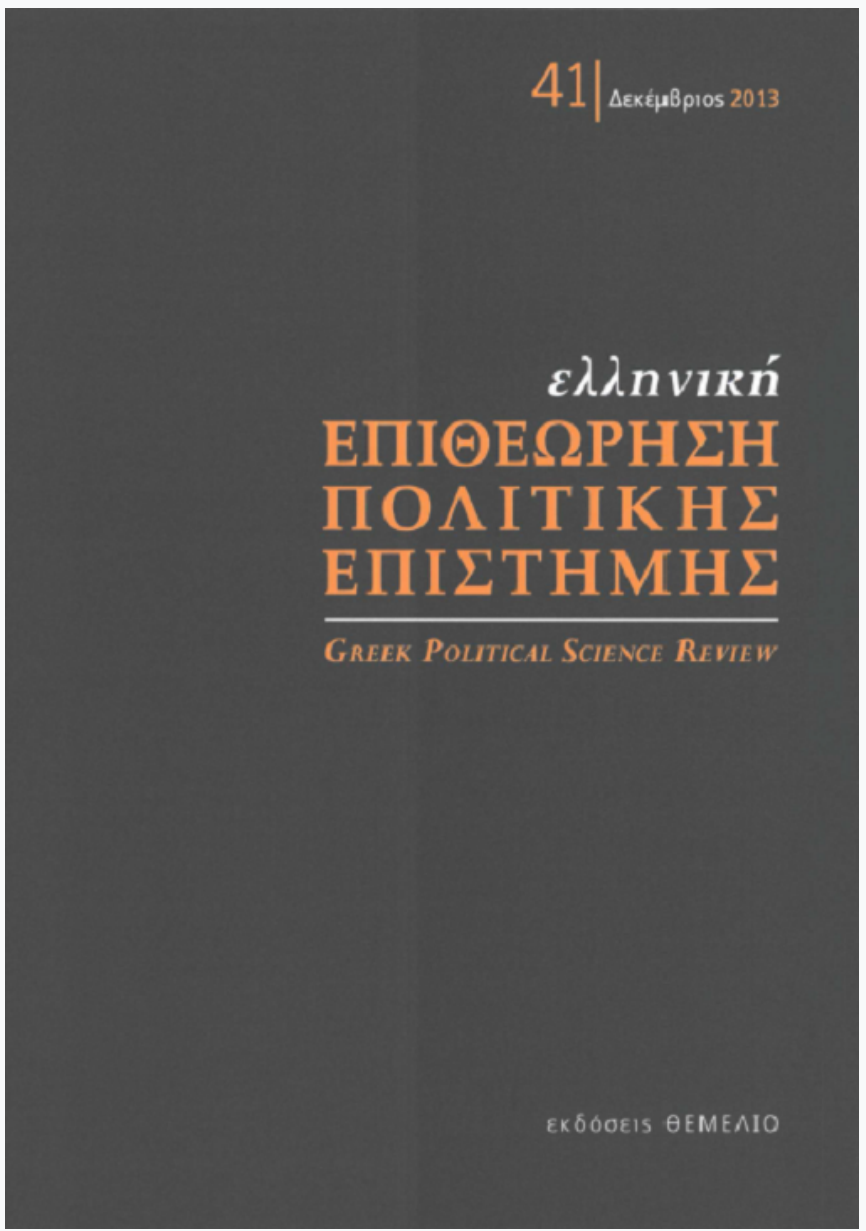

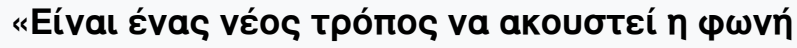

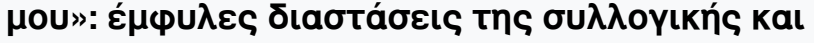

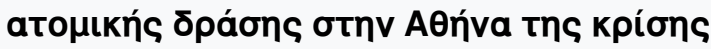

Mavíva Какєпа́кп

doi: $10.12681 / \mathrm{hpsa} .14535$

Copyright @ 2017, Mavíva Какєпákn

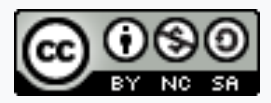

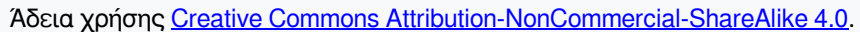

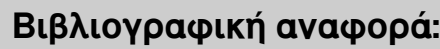

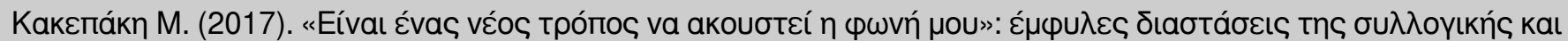

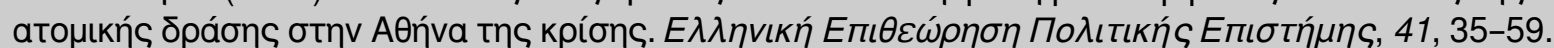

https://doi.org/10.12681/hpsa.14535 


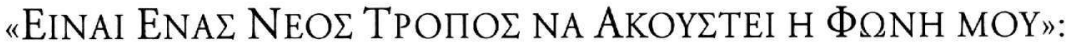

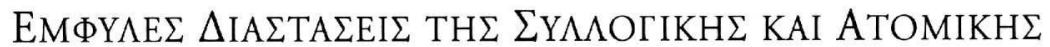

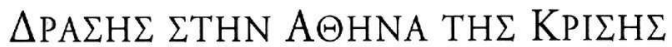

\section{Mavíva Kakenákn*}

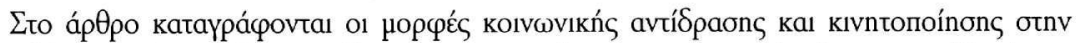

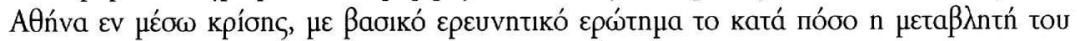

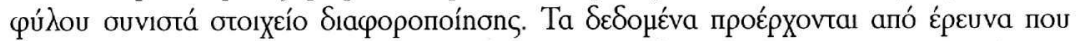

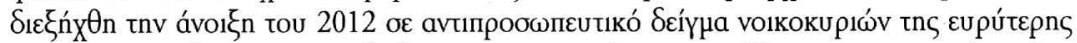

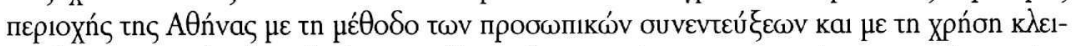

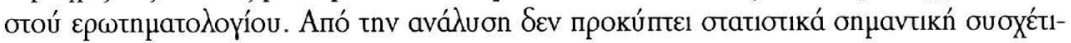

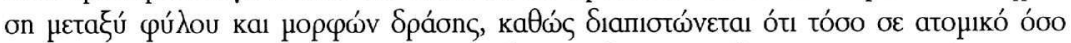

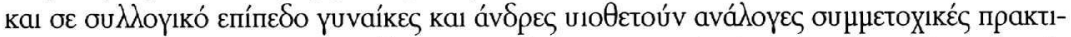

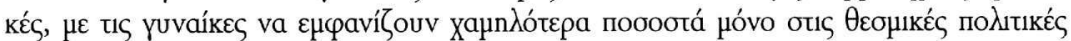

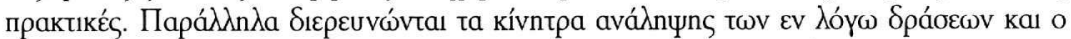

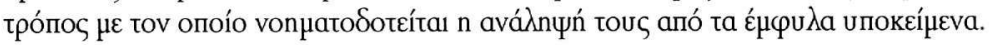

\section{1. $\mathrm{EI} \Sigma \mathrm{A} \Gamma \Omega \Gamma \mathrm{H}$}

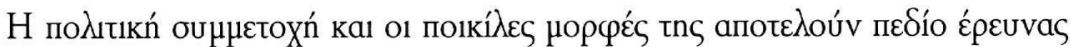

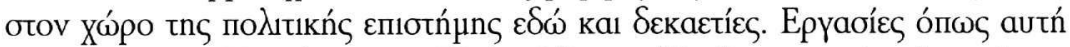

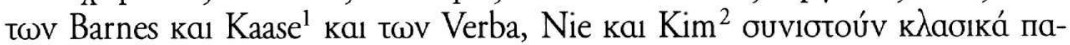

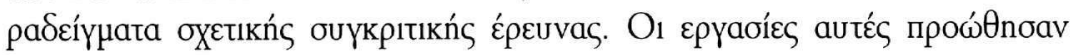

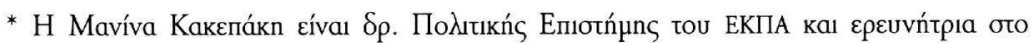

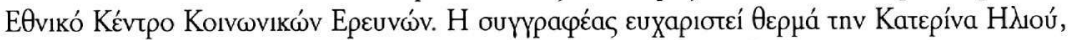

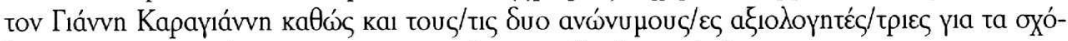

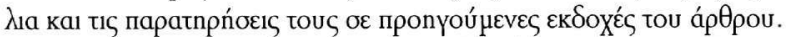

1.S. Barnes - M. Kaase k.á., Political Action. Mass Participation In Five Western Democracies, Sage, Beverly Hills-Kaגıøópvia 1979.

2. S. Verba - N.H. Nie - Jae-On Kim, Participation and political equality: A seven nation comparison, Chicago University Press, ¿ıkáyo 1978. 


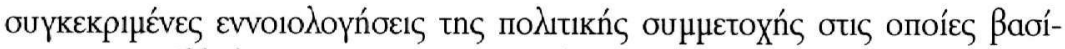

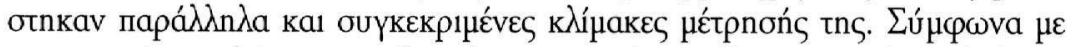

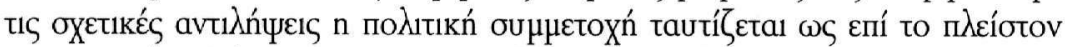

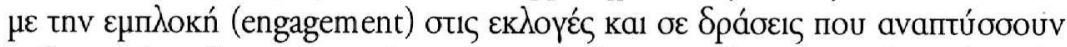

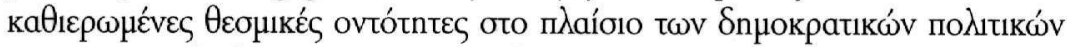

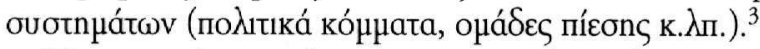

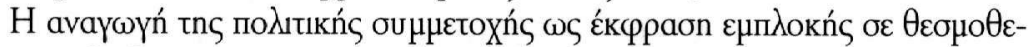

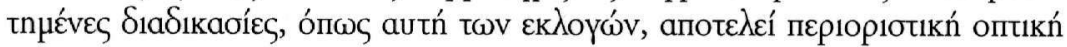

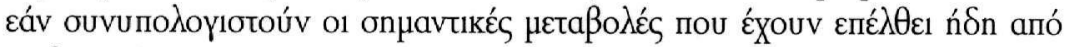

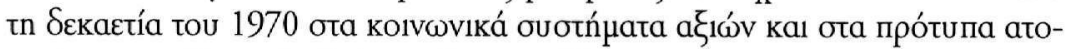

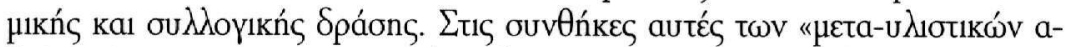

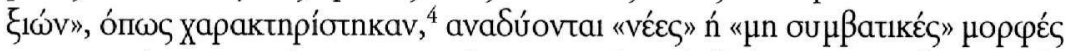

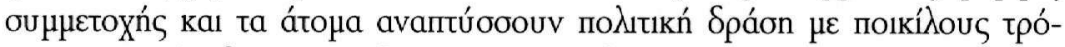

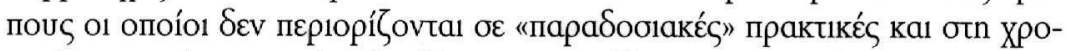

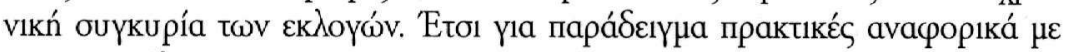

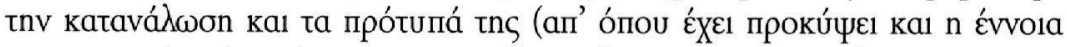

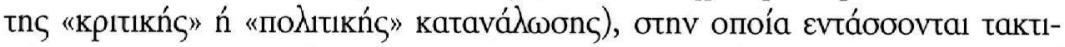

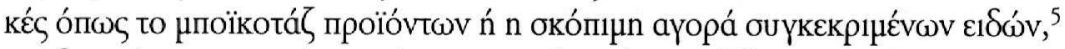

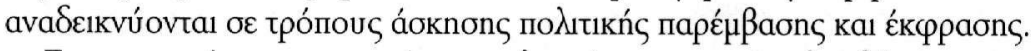

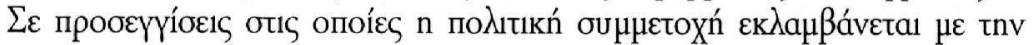

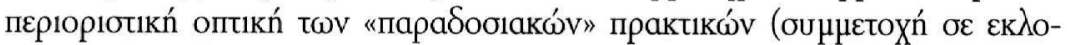

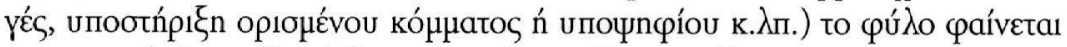

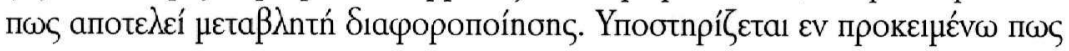

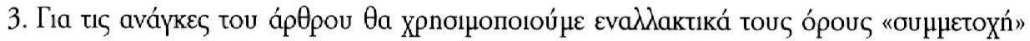

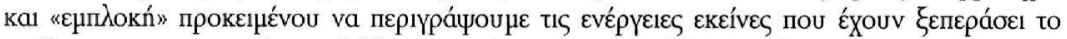

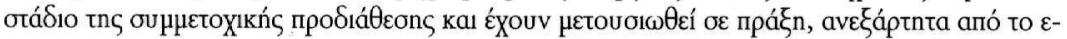

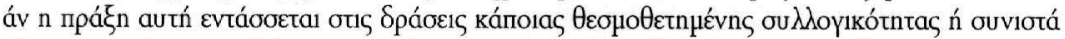

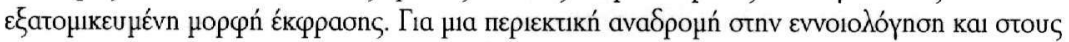

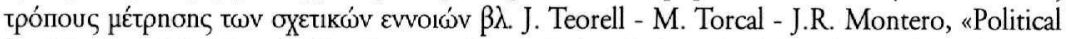
Participation. Mapping the Terrain", бто J. van Deth к.á. (впцц.), Citizenship and Involvement

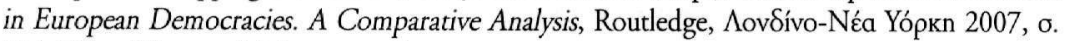

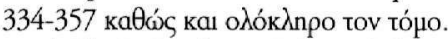

4. $\mathrm{B} \lambda$. R. Ingehart, Culture shift in advanced industrial society, Princeton University Press, Princeton 1990.

5. B $\lambda$. P. Norris, Democratic Phoenix: Reinventing Political Activism, Cambridge University Press, Néa Yópkn 2002' L.S. Yates, "Critical Consumption», European Societies, tóp. 13, TX. 2, 2011, o. 191-217 D. Stolle - M. Hooghe - M. Micheletti, «Politics in the supermarket: Political consumerism as a form of political participation", International Political Science Review, tó . 26, тx. 3, 2005, б. 245-269. 


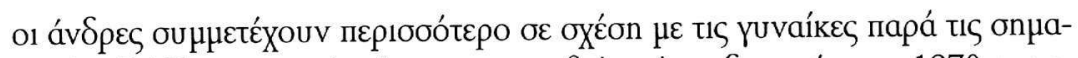

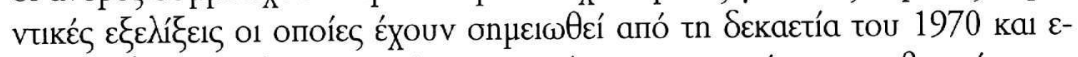

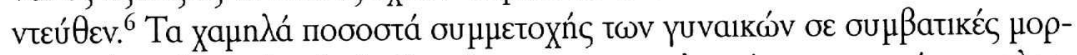

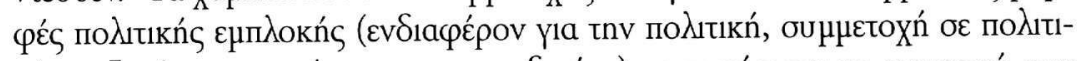

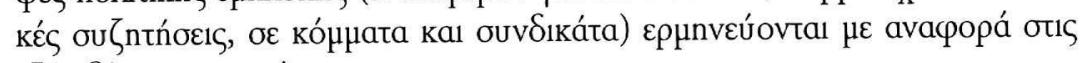

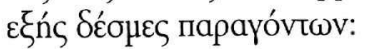

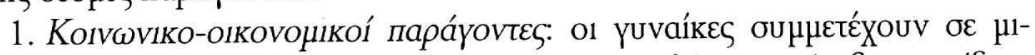

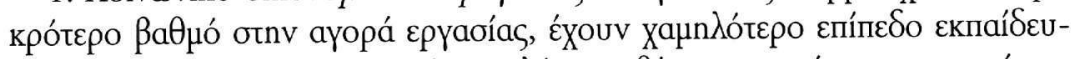

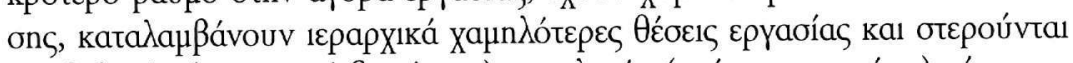

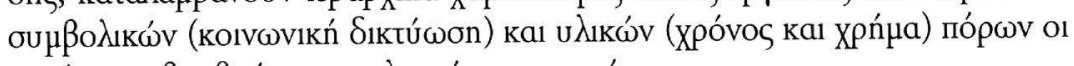

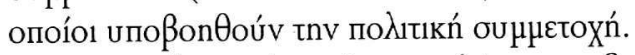

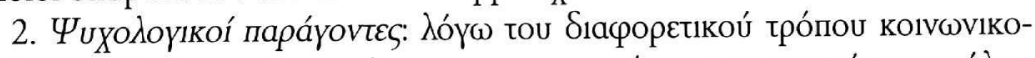

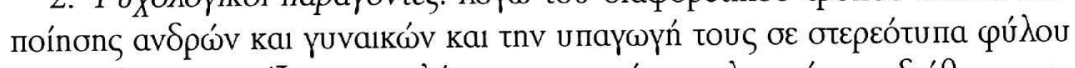

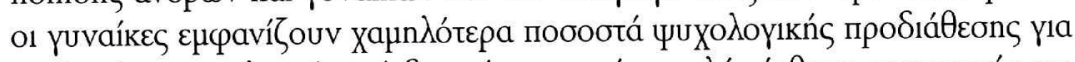

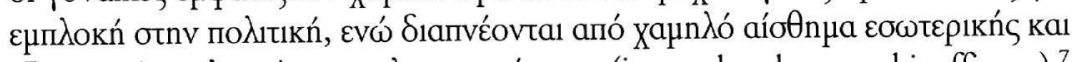

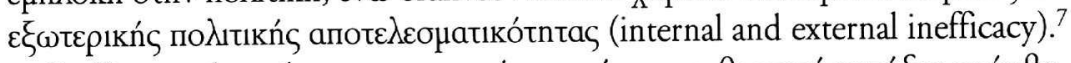

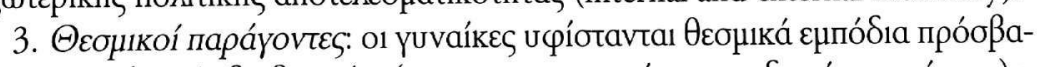

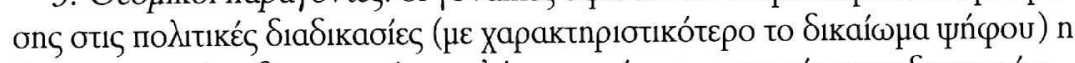

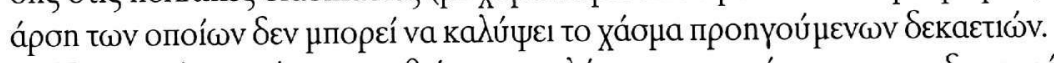

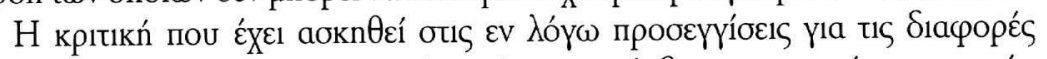

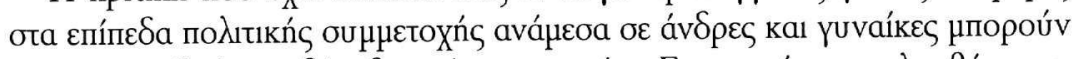

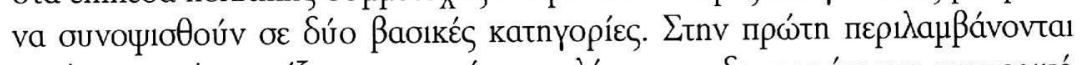

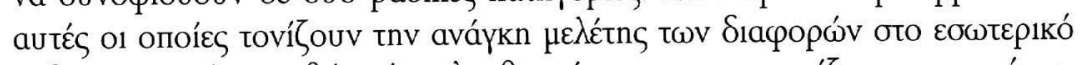

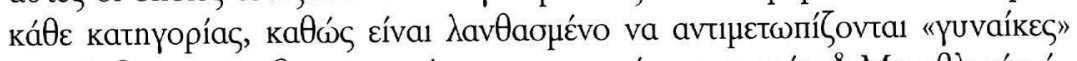

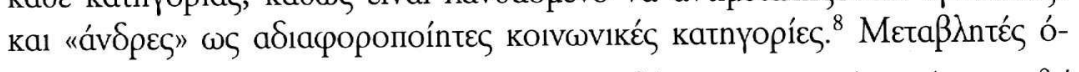

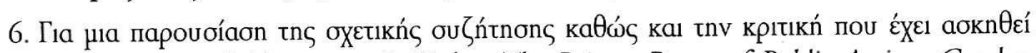
$\beta \lambda$. N. Burns - K.L. Schlozman - S. Verba, The Private Roots of Public Action: Gender, Equality, and Political Participation, Harvard University Press, Cambridge MA 2001, 0. 61

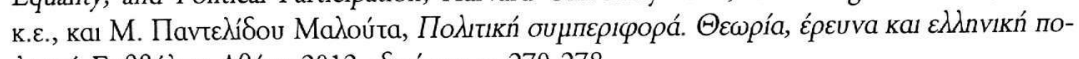

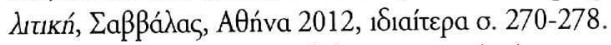

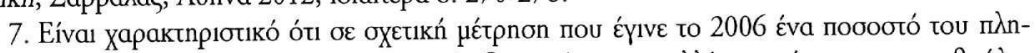

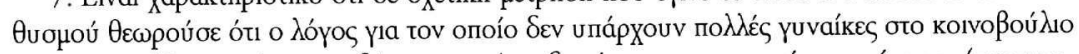

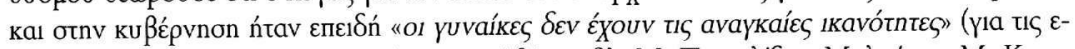

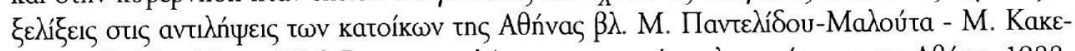

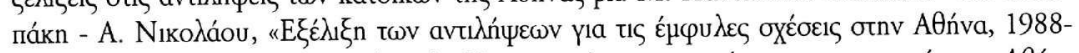

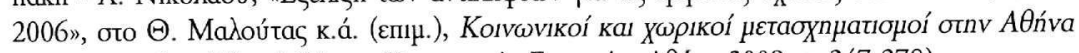

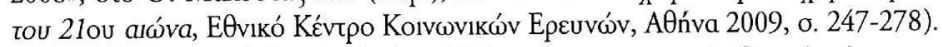

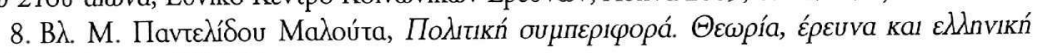
подııки́, ó.п., о. 276-277. 


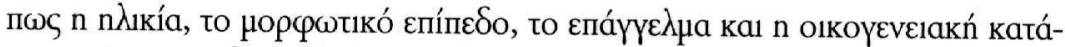

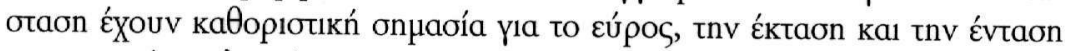

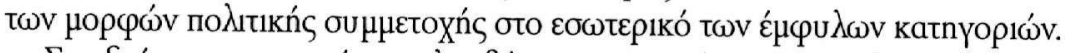

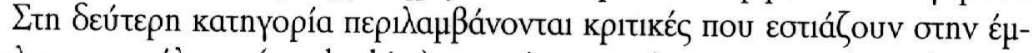

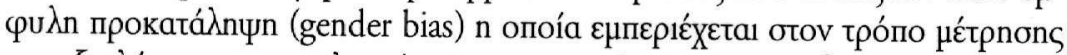

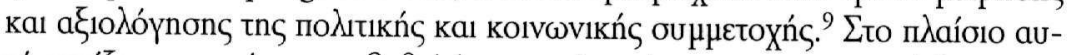

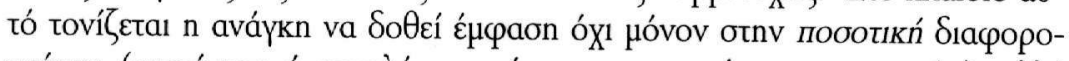

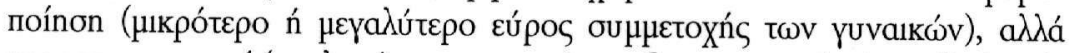

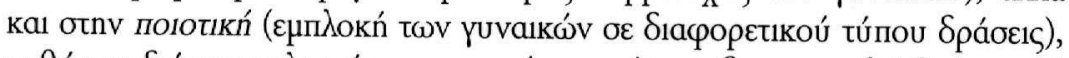

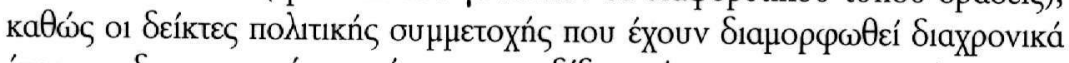

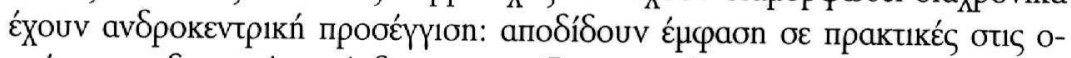

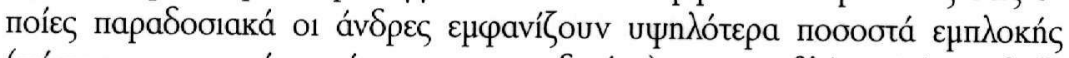

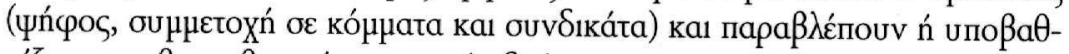

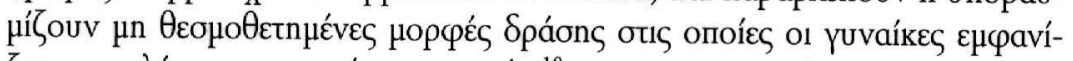

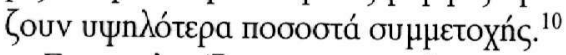

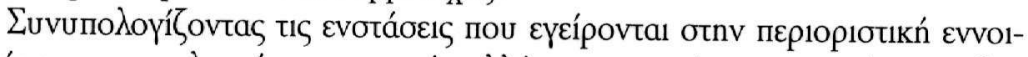

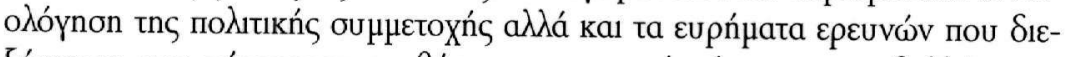

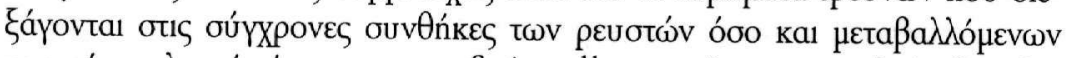

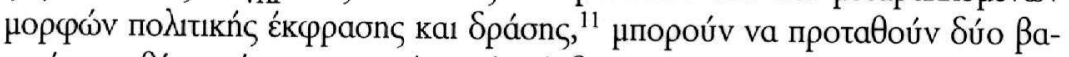

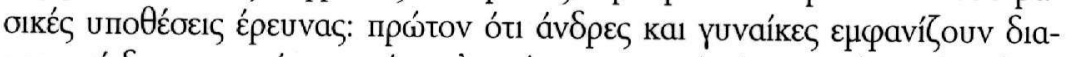

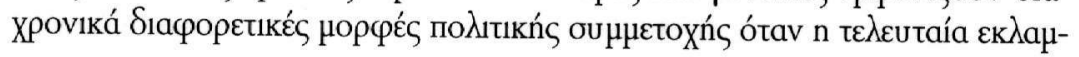

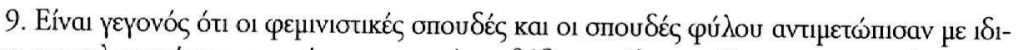

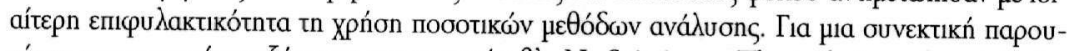

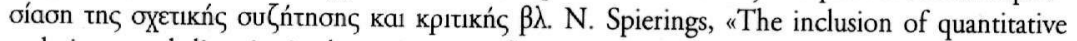
techniques and diversity in the mainstream feminist research", European Journal of Women's Studies, tón. 19, тx. 3, 2012, о. 331-347.

10. B . N. Burns - K.L. Schlozman - S. Verba, The Private Roots of Public Action: Gender, Equality, and Political Participation, ó.п., о. 63 ka V. Randall, Women and Politics. An international perspective, University of Chicago Press, इıкáyo 1987.

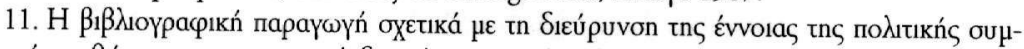

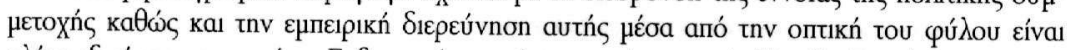

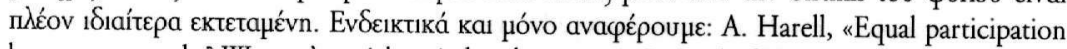
but separate paths? Women's social capital and turnout", Journal of Women, Politics \& Policy, tX. 30, 2009, б. 1-22* R. Campbell, "Leaders, footsoldiers and befrienders: The gendered nature of social capital and political participation in Britain", British Politics, tóp. 8, тx. 1, 2013, o. $28-50^{\circ} \mathrm{H}$. Coffe - C. Bolzendahl, «Same game, different rules? Gender differences in political participation», Sex Roles, tx. 62, 2010, ๙. 318-333 D. Stolle - M. Hooghe, «Shifting Inequalities», European Societies, tóp. 13, tү. 1, 2011, б. 119-142, ka1 A. Gallego, «Unequal Political Participation in Europe», International Journal of Sociology, tóp. 37, זx. 4, 2007, б. 10-26. 


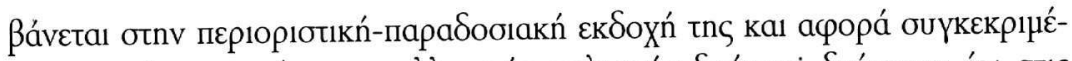

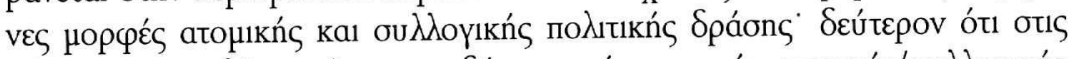

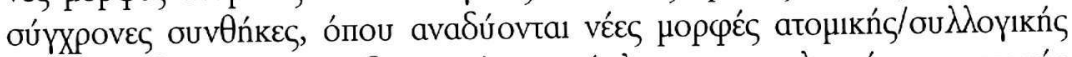

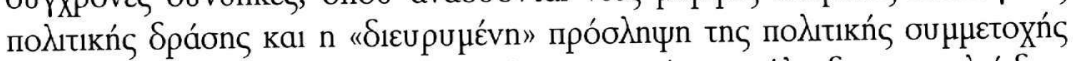

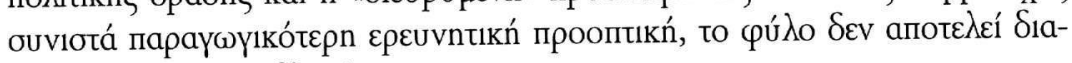

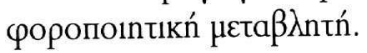

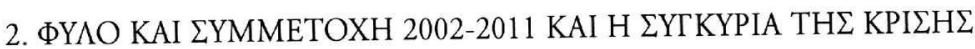

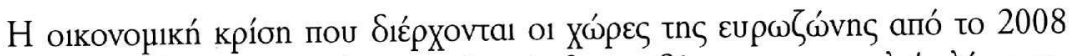

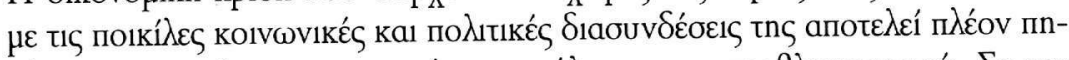

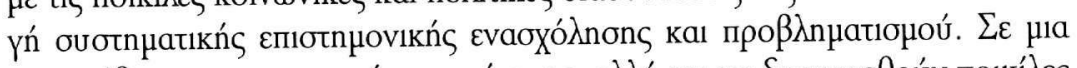
проoná

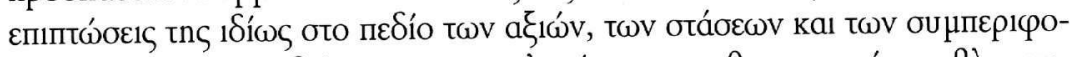

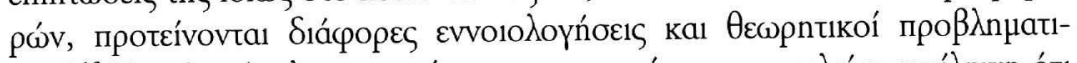

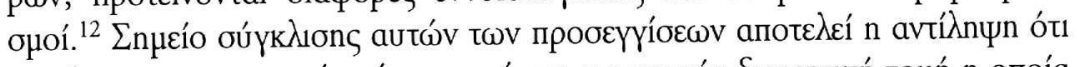

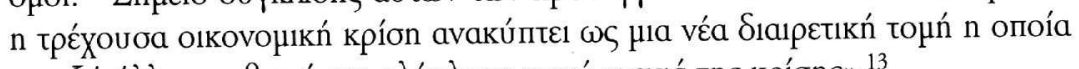

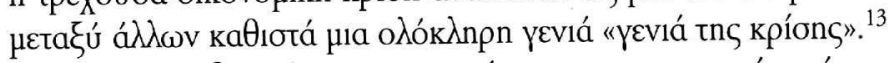

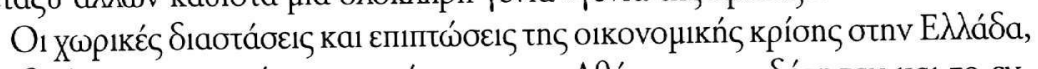

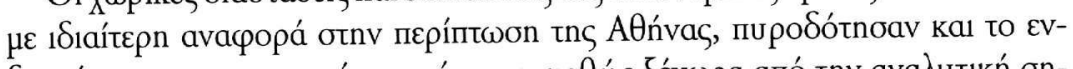

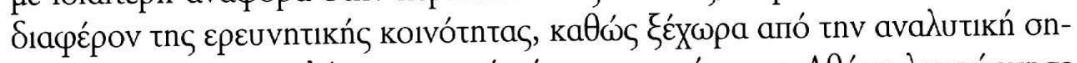

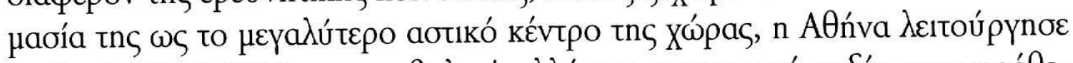

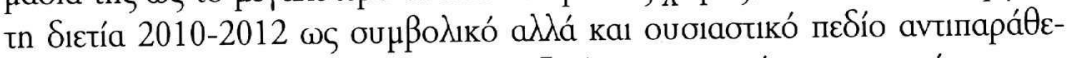

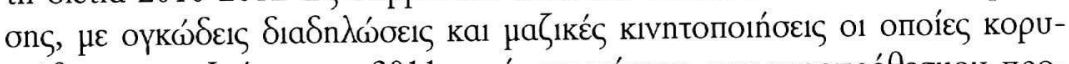

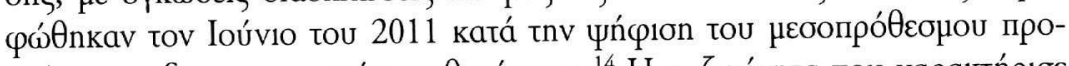

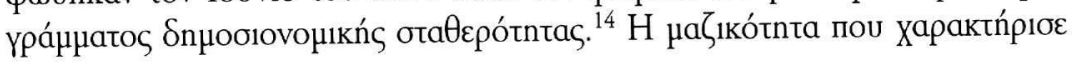

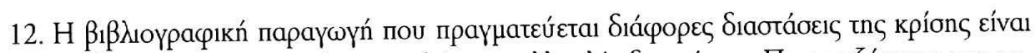

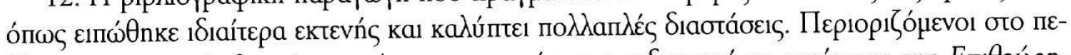

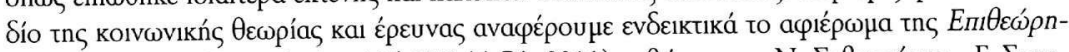

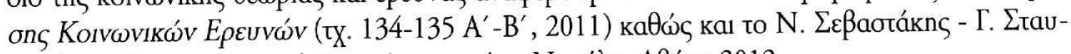

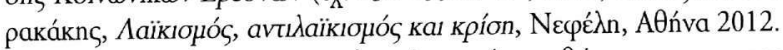

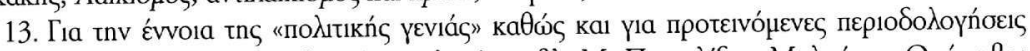

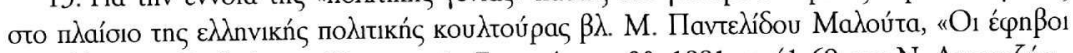

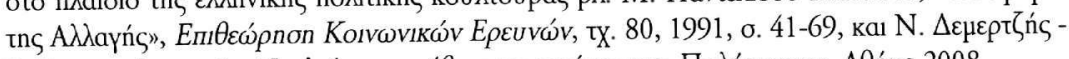

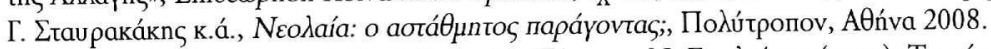

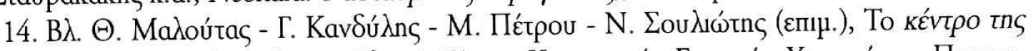

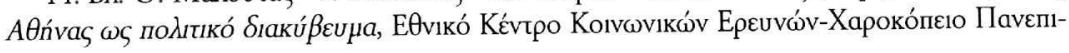




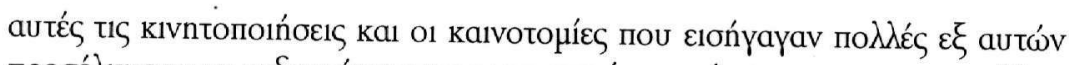

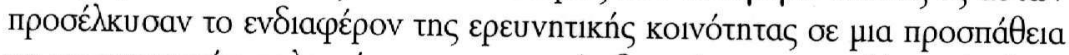

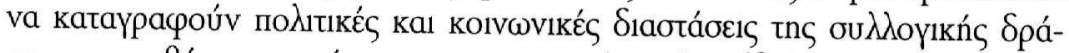

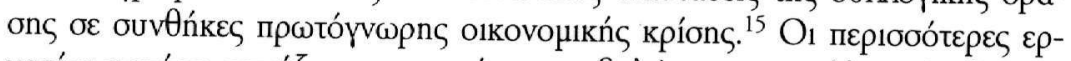

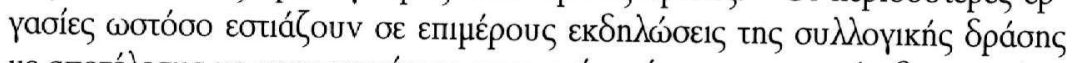

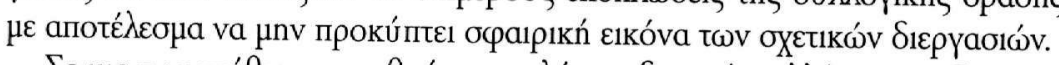

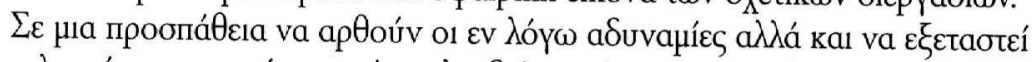

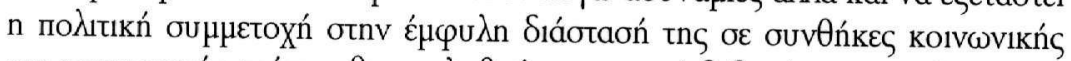

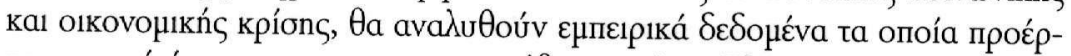

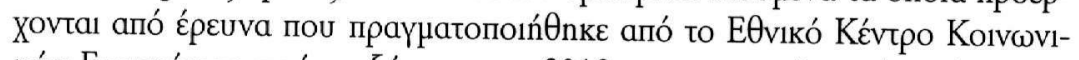

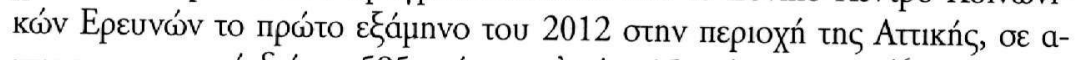

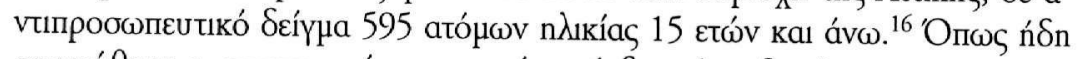

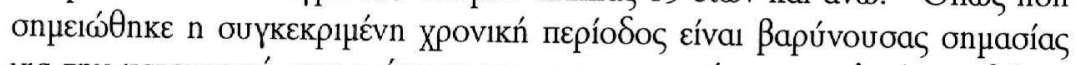

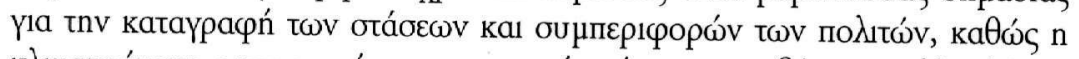

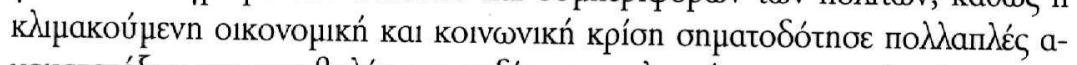

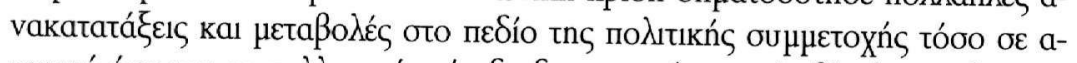

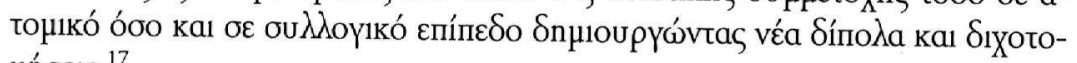
นńđeıs. ${ }^{17}$

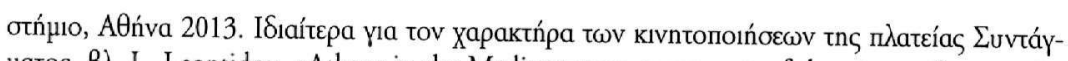
$\mu$ atos, $\beta \lambda$. L. Leontidou, «Athens in the Mediterranean movement of the piazzas. Spontaneity in material and virtual public spaces», City, tóp. 16, тx. 3, 2012, б. 299-312, ka1 D. Dalakoglou, "Beyond Spontaneity. Crisis, violence and collective action in Athens", City, tóp. 16, тx. 5, 2012, б. 535-545.

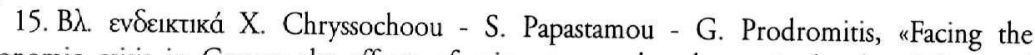
economic crisis in Greece: the effects of grievances, real and perceived vulnerability, and emotions towards the crisis on reactions to austerity measures», Journal of Social Science Education , tón. 12, тX. 1, 2013, o. 41-49.

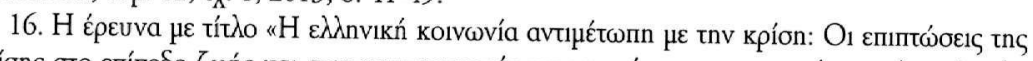

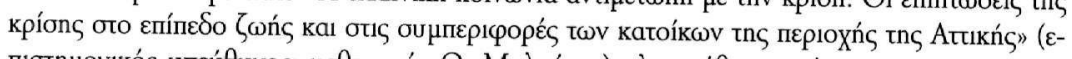

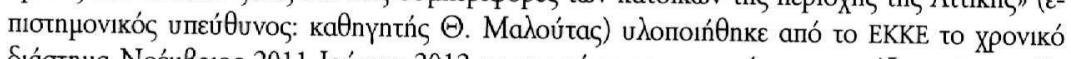

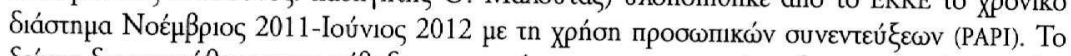

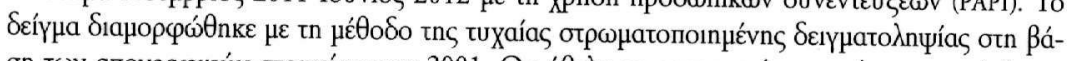

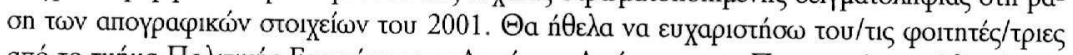

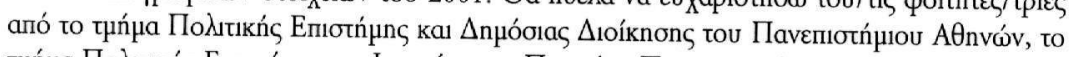

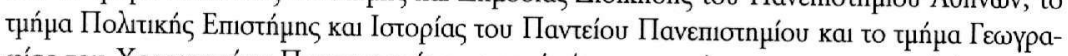

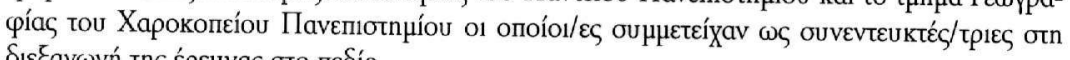

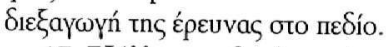

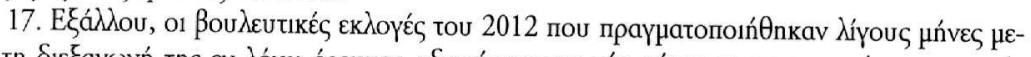

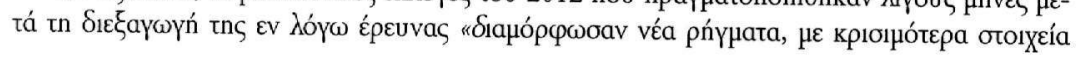




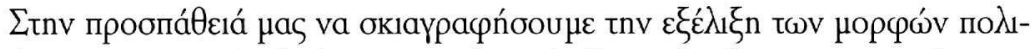

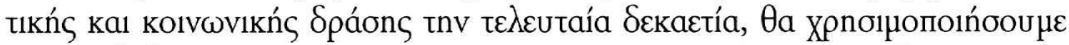

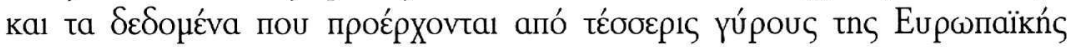

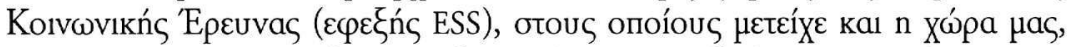

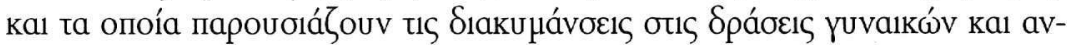

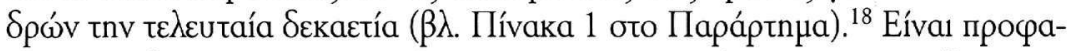

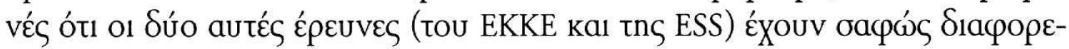

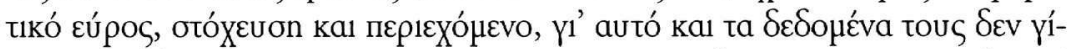

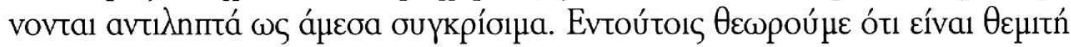

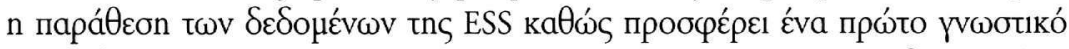

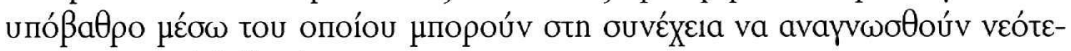

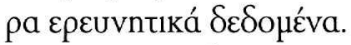

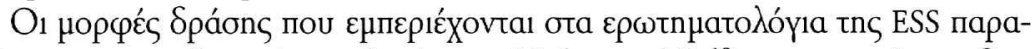

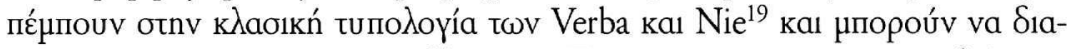

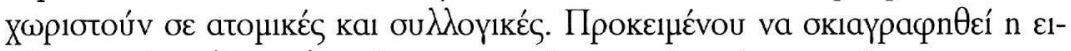

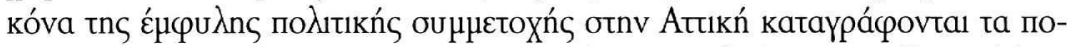

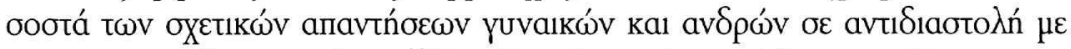

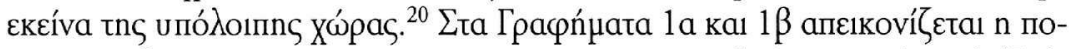

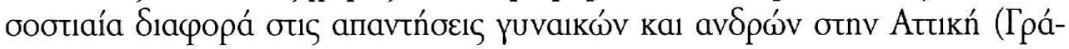

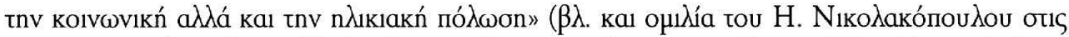
11.03.2013, http://www.blod.gr/lectures/Pages/viewlecture.aspx?LectureID=744, прóoßaon oथा 30.07.2013).

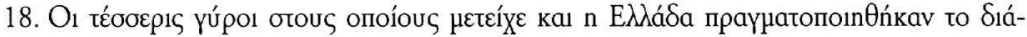
oтnнa Iavouapíou-Maptíou 2003 [ESS 2002], lavouapíou-Maptíou 2005 [ESS 2004], Iouגí-

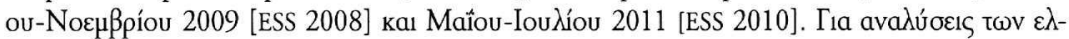

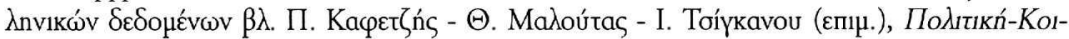

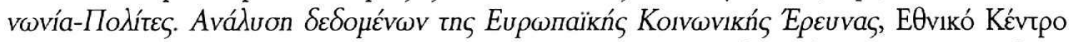

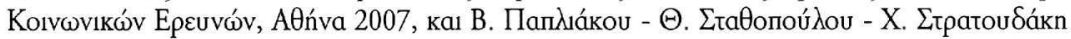

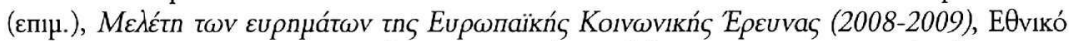

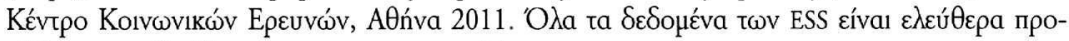

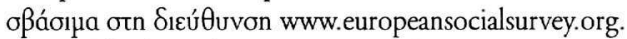

19. Bג. S. Verba - N.H. Nie. Participation in America: Political democracy and social equality, Harper and Row, Néa Yópkn 1972, ka S. Verba - N.H. Nie - Jae-On Kim, Participation and political equality: $A$ seven nation comparison, ó.n.

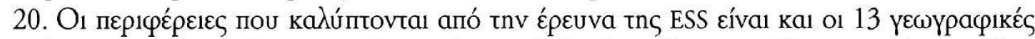

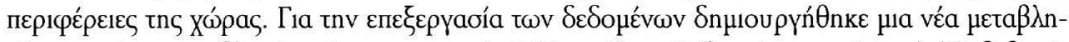

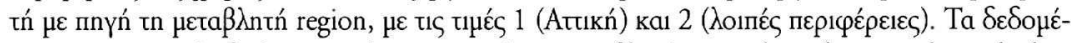

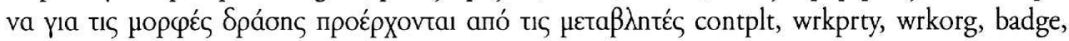
sgnptit, pbldmn kau bctprd. 


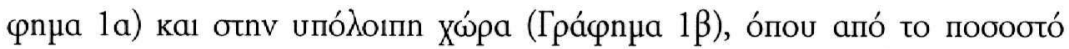

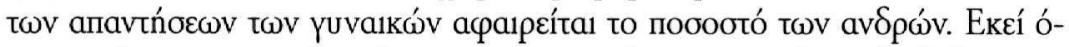

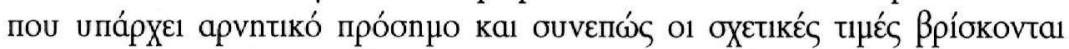

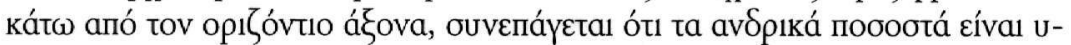

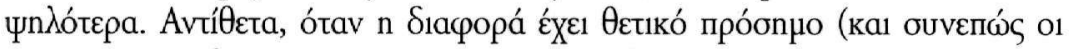

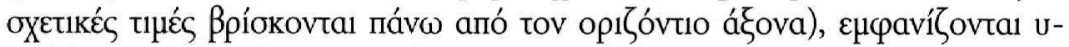

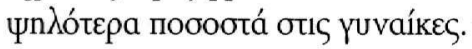

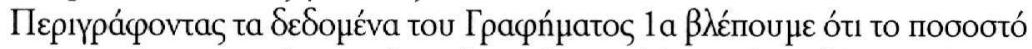

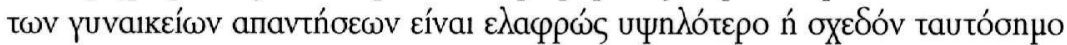

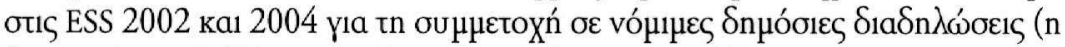

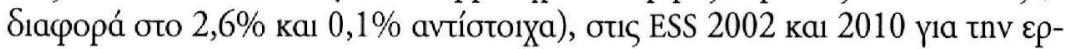

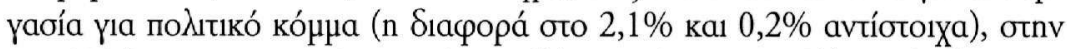

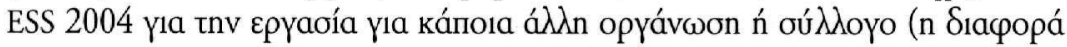

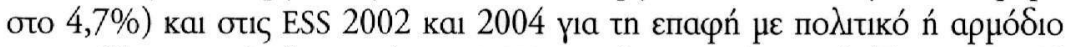

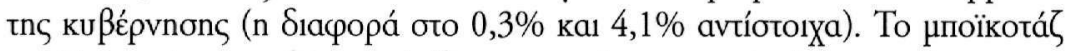

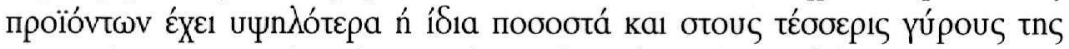

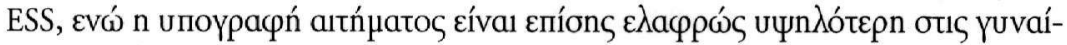

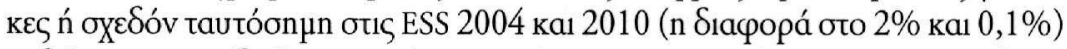

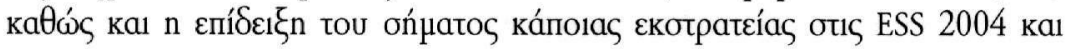

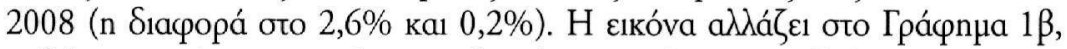

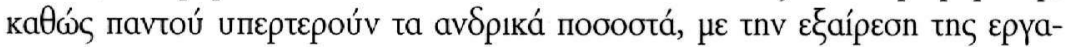

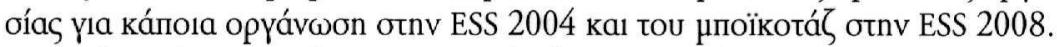

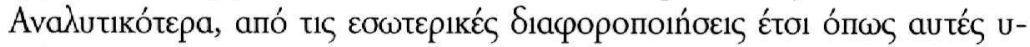

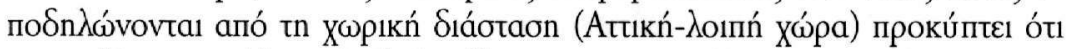

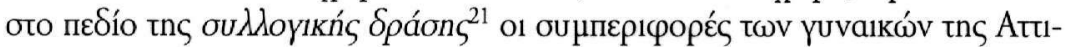

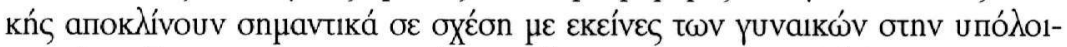

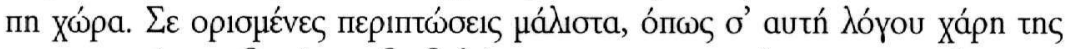

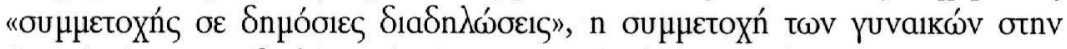

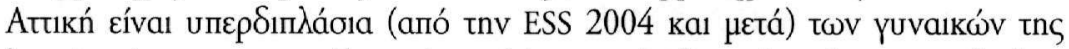

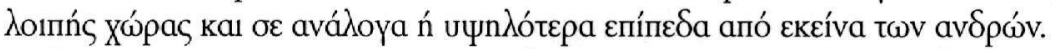

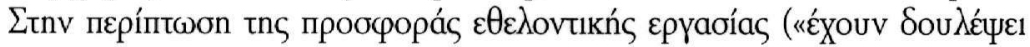

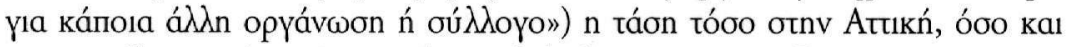

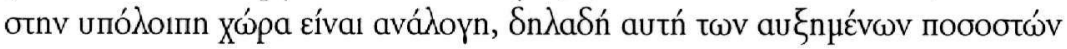

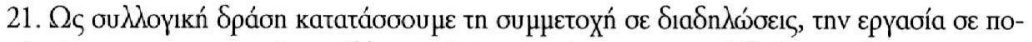

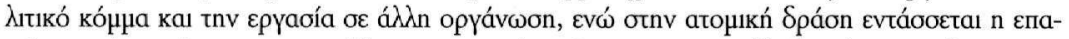

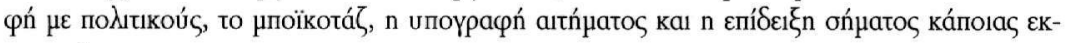
oтратв́́as. 


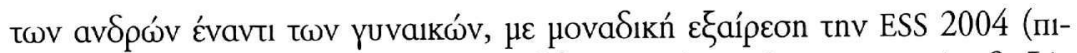

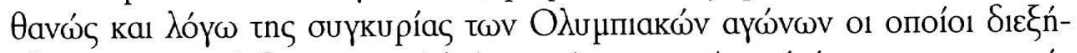

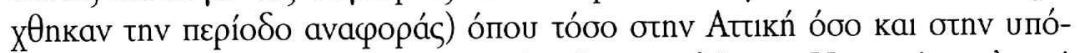

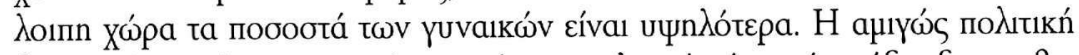

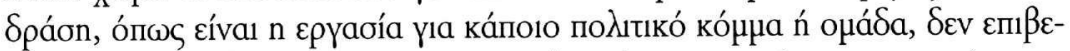

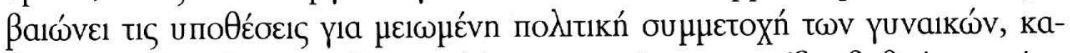

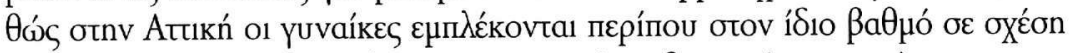

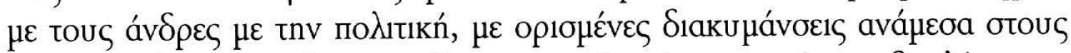

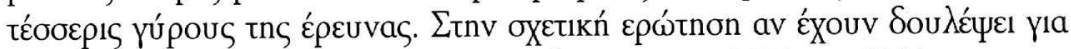

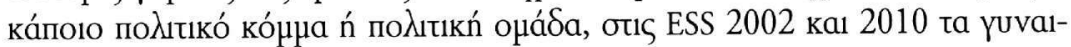

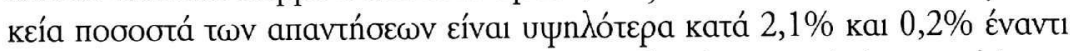

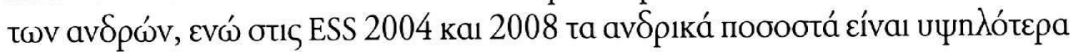

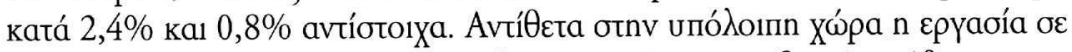

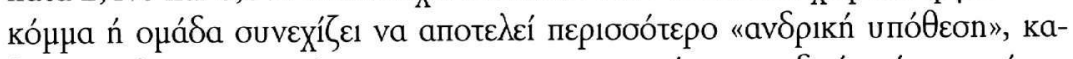

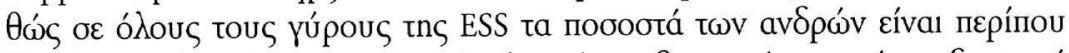

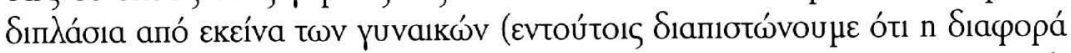

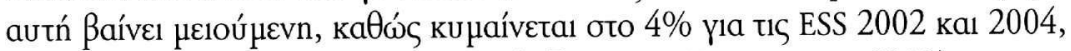

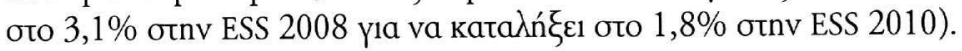

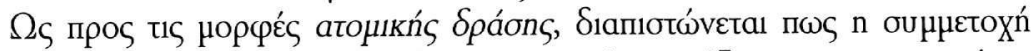

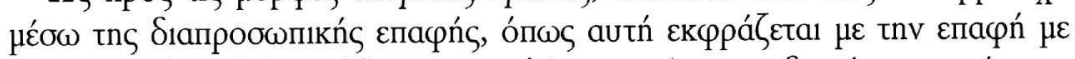

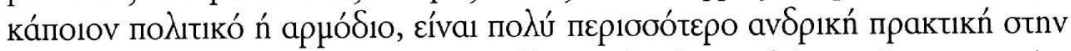
uпó

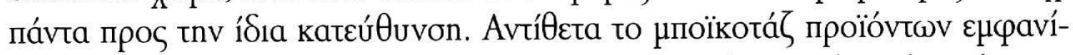

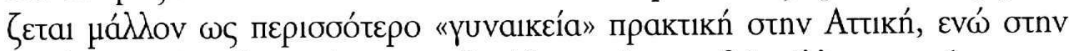
uпó

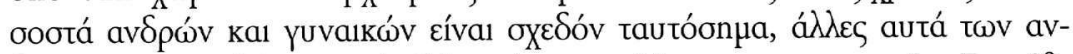

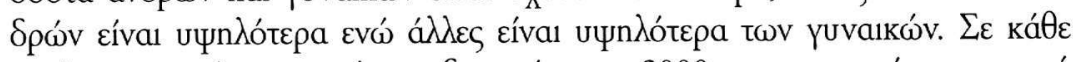

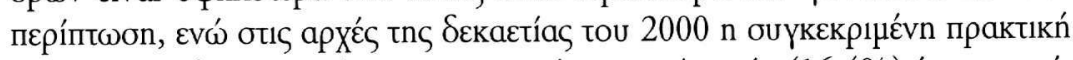

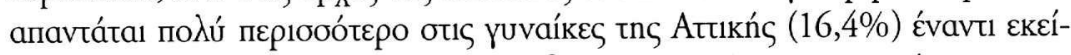

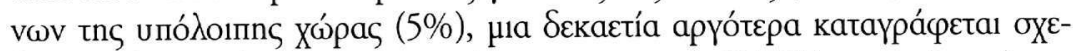

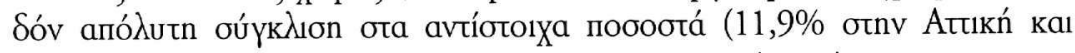

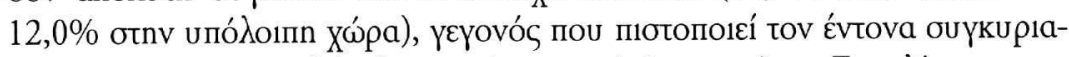

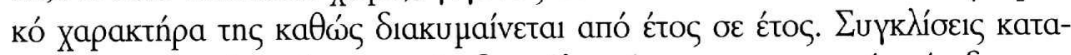

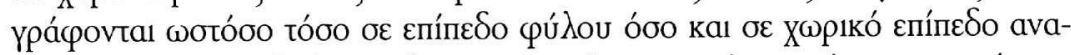


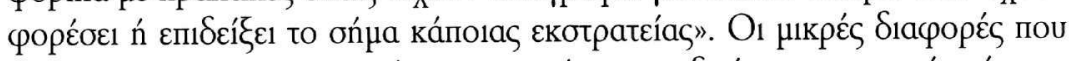

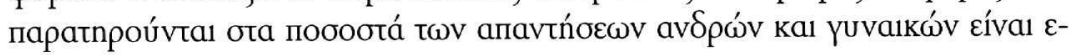




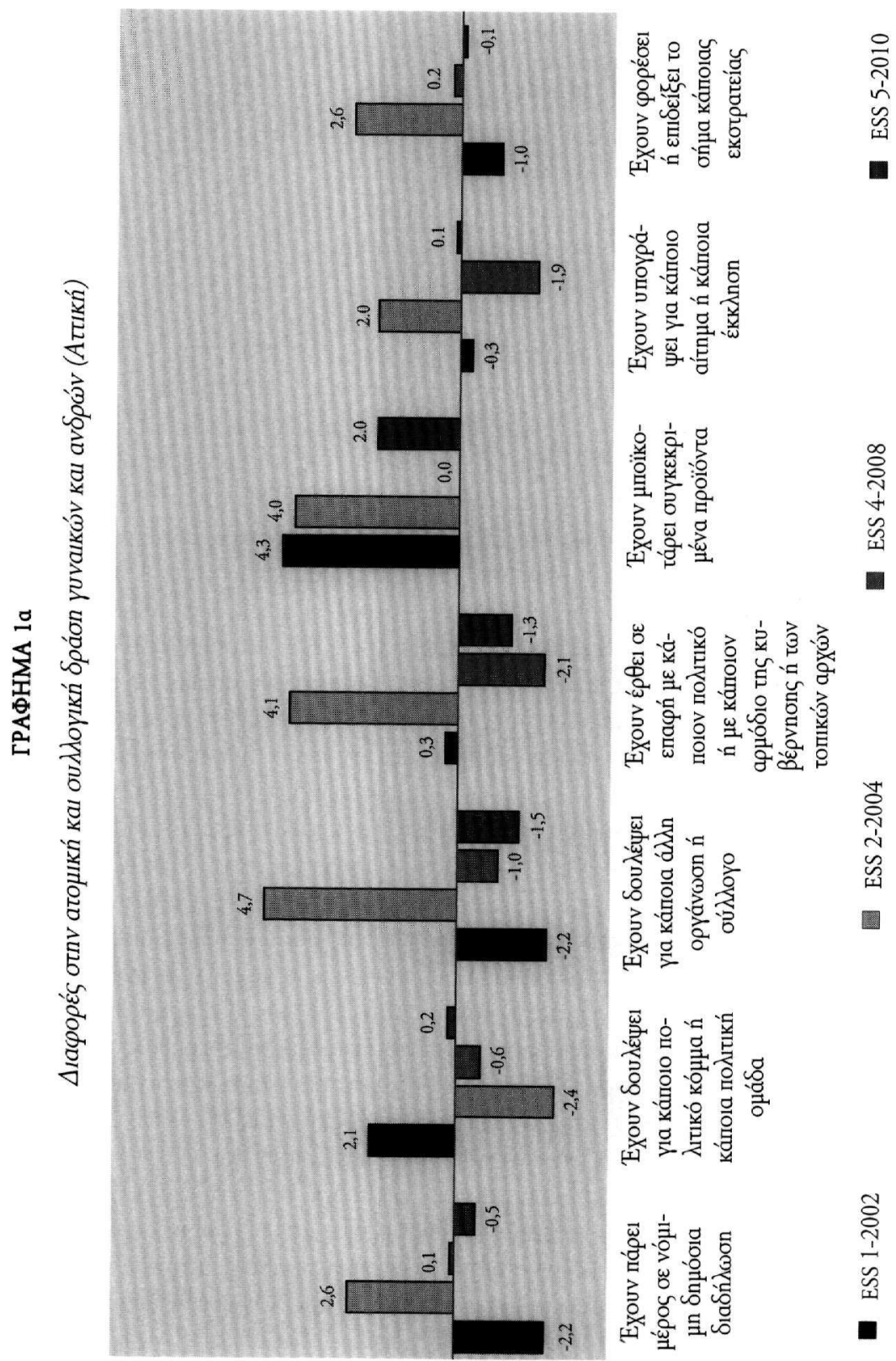




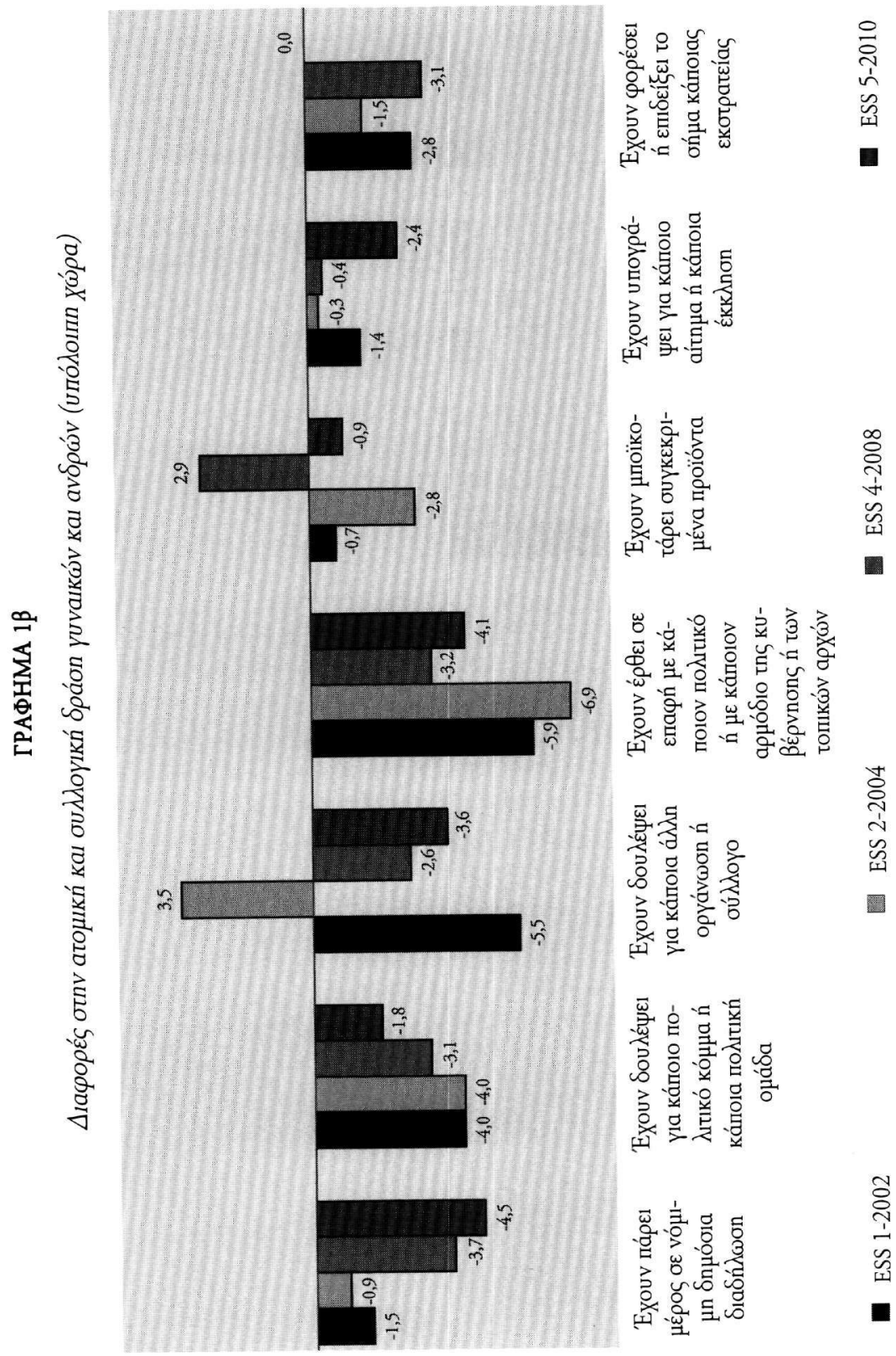




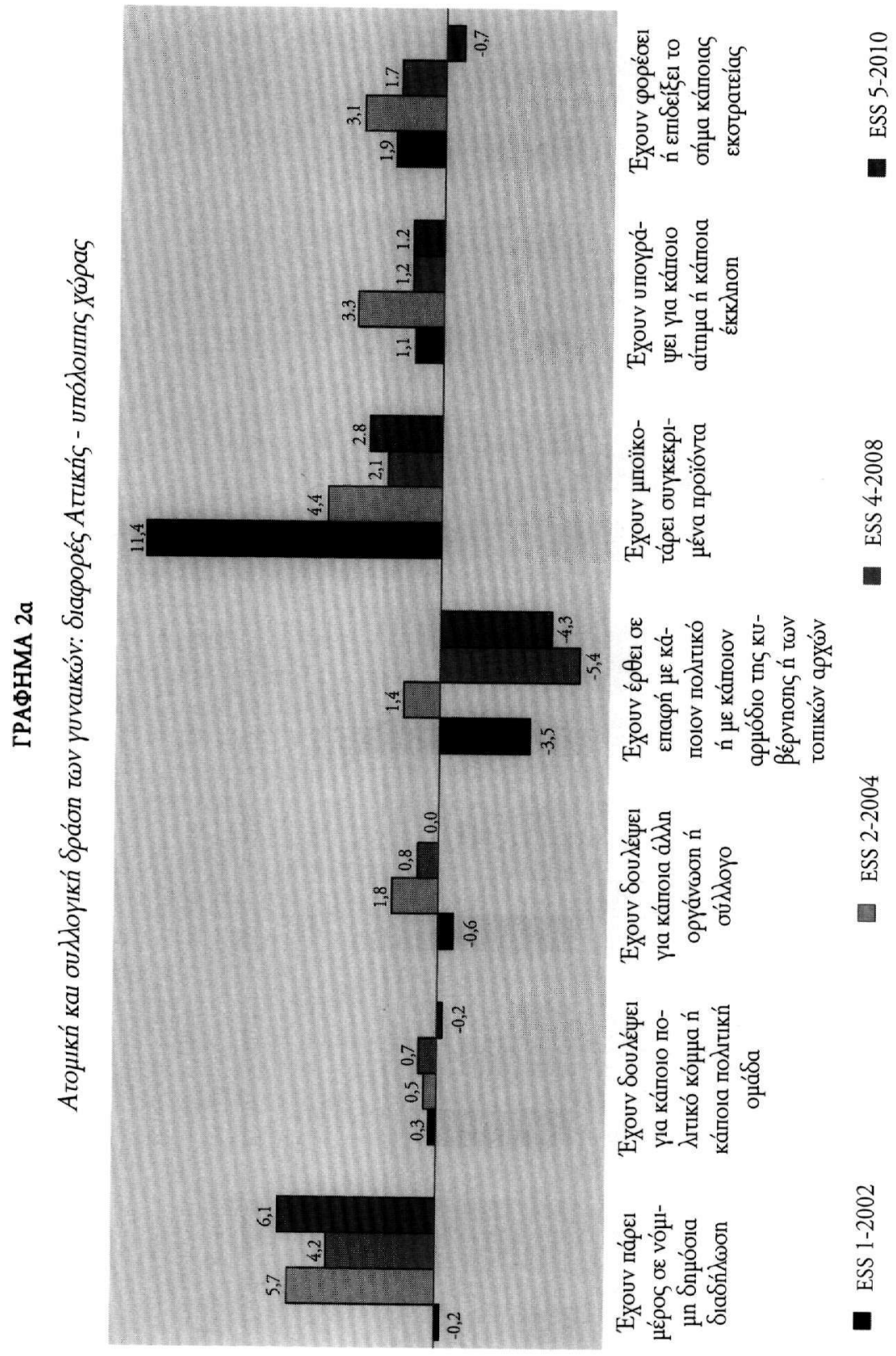




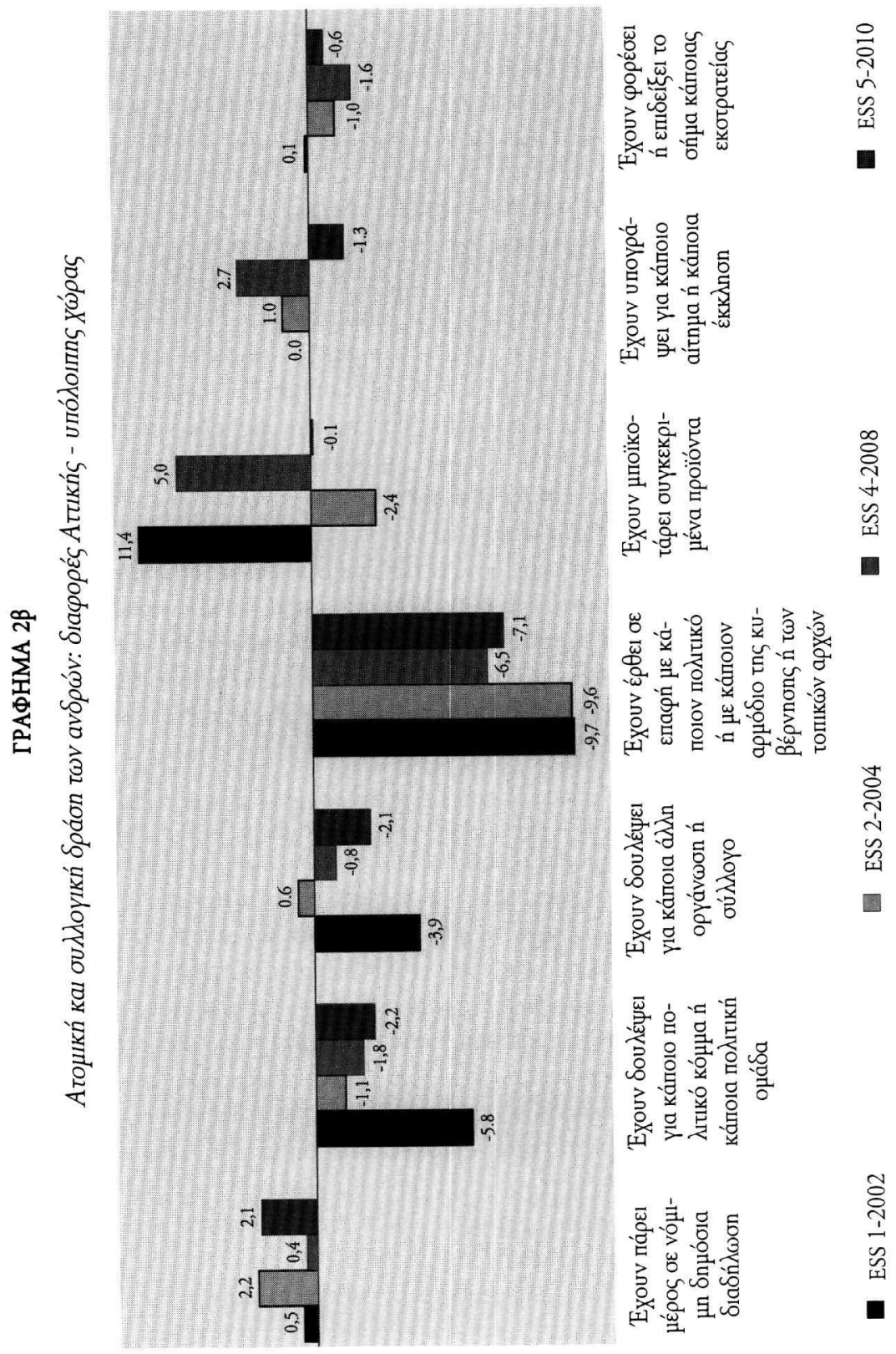




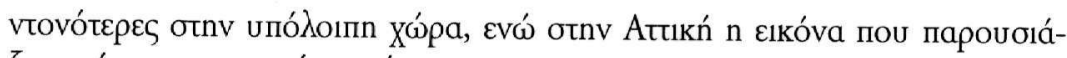

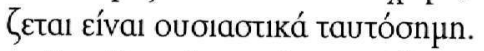

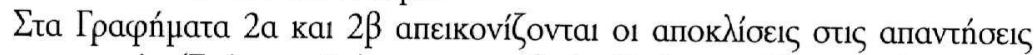

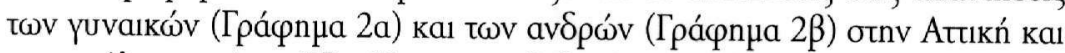

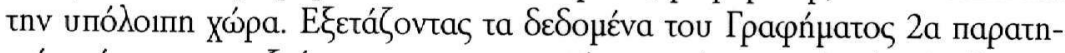

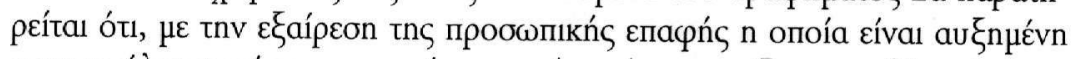

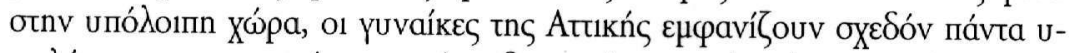

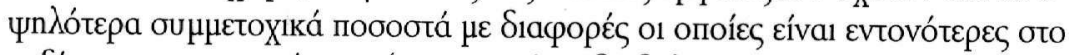

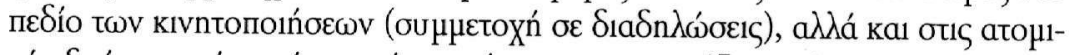

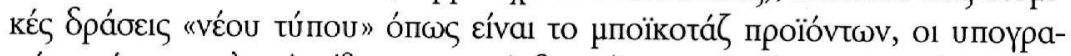

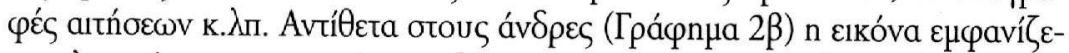

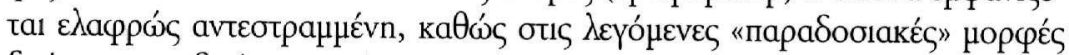

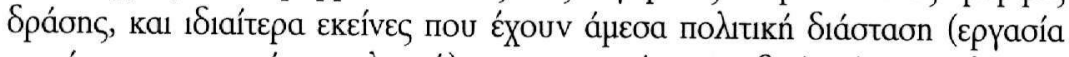

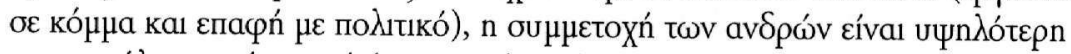

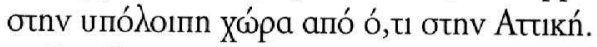

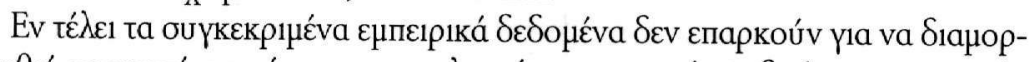

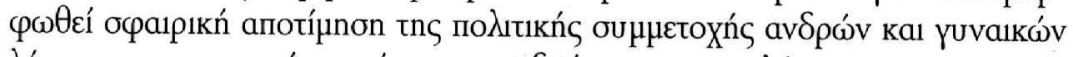

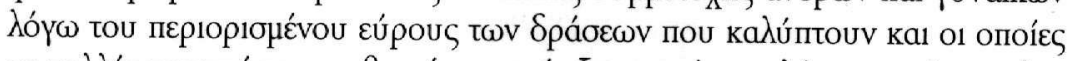

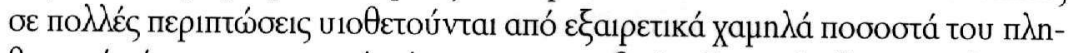

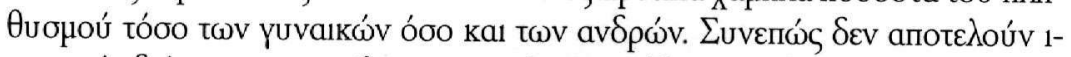

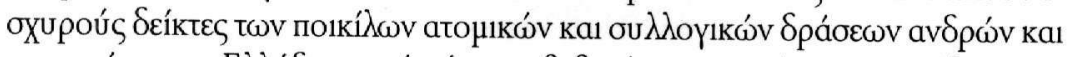

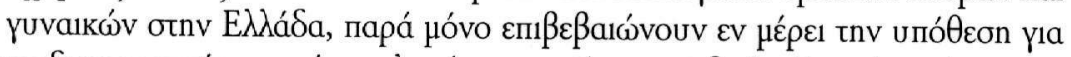

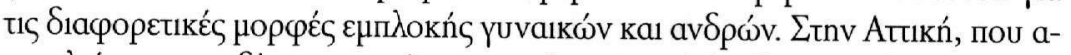

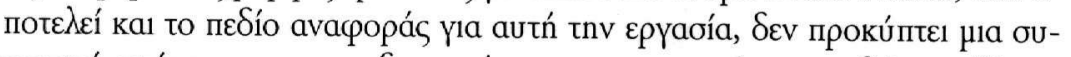

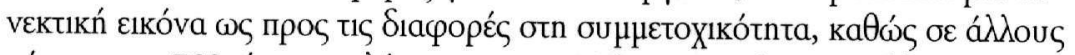

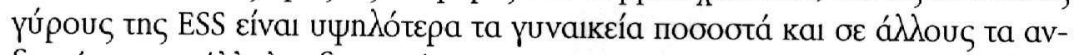

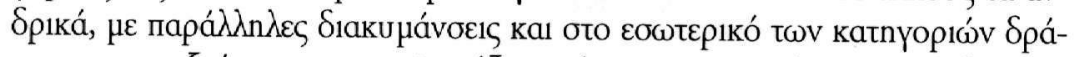

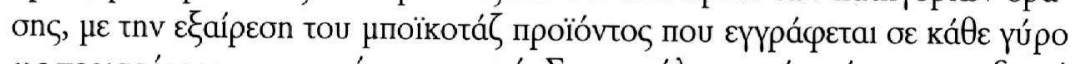

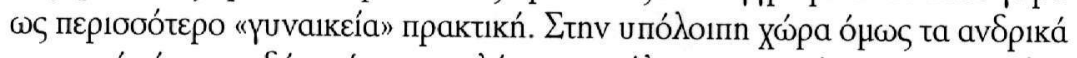

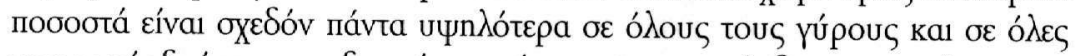

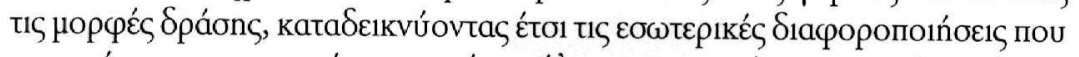

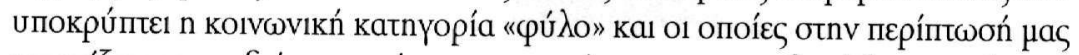

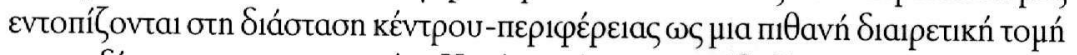

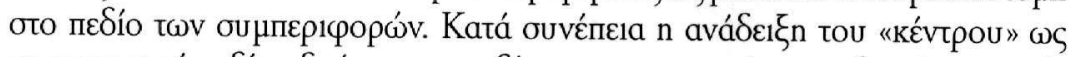

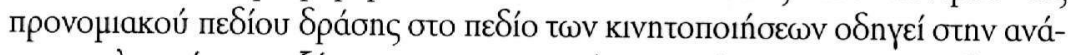

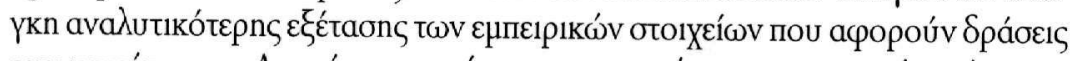

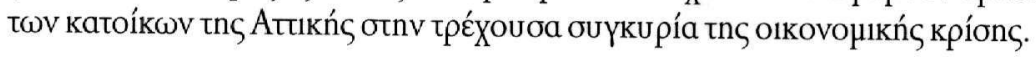




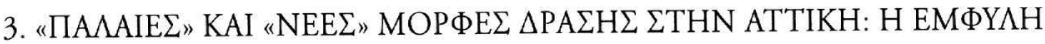 $\triangle \mathrm{IA} \Sigma \mathrm{TA} \Sigma \mathrm{H}$}

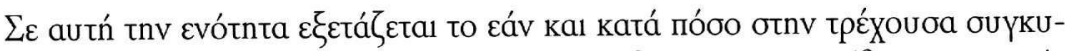

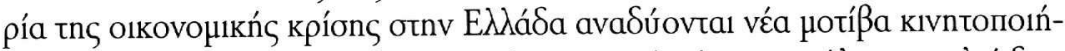

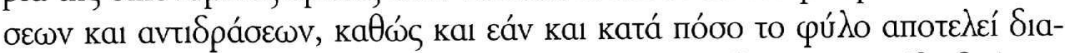

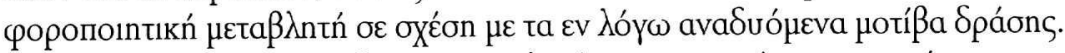

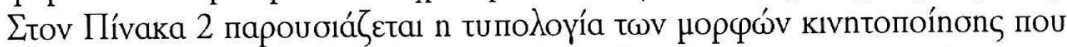

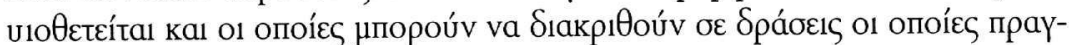

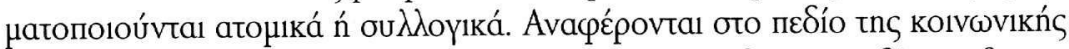

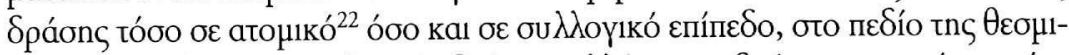

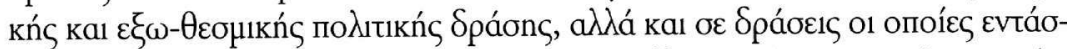

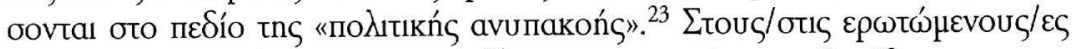

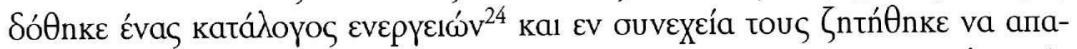

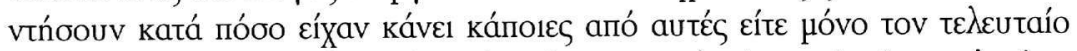

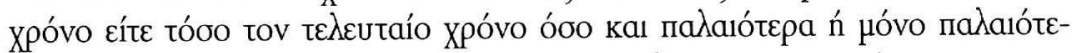

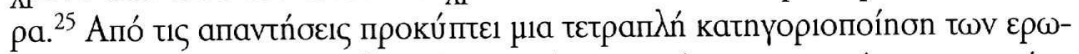

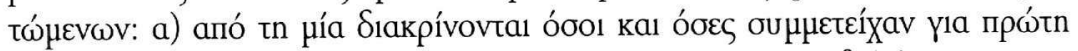

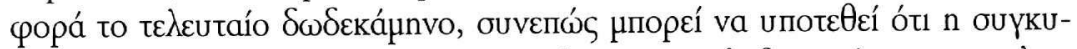

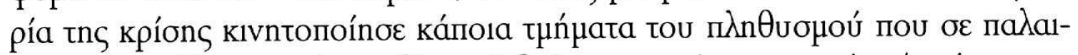

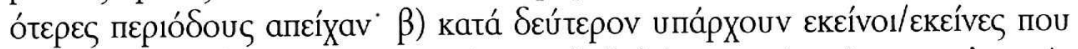

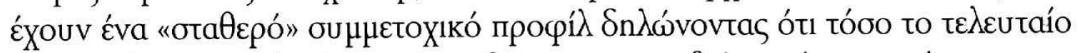

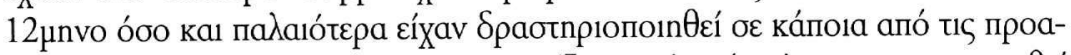
va

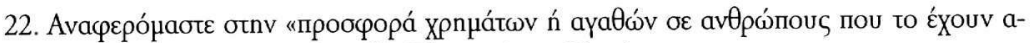

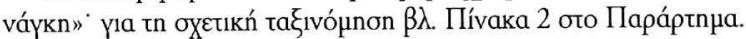

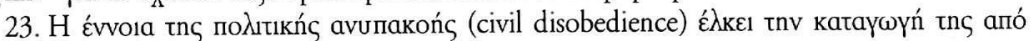

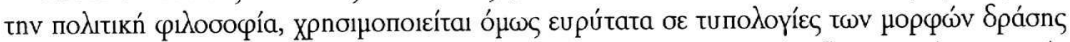

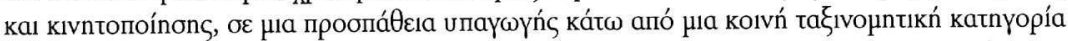

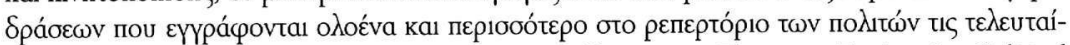

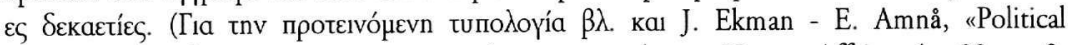
participation and civic engagement: towards a new typology", Human Affairs, tóp. 22, тx. 3, 2012, ๙. 283-300).

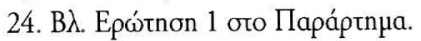

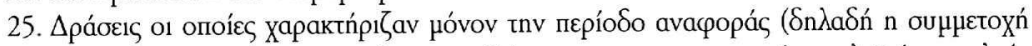

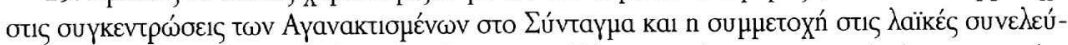

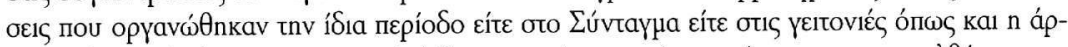

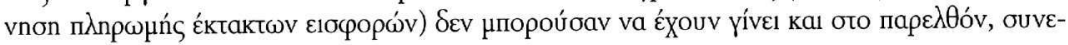

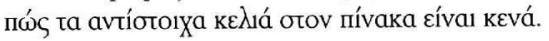




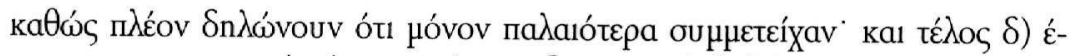

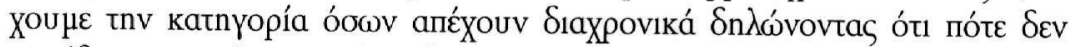

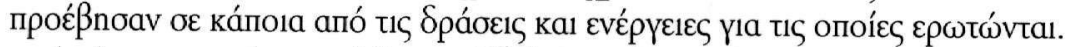

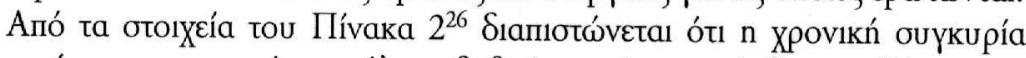

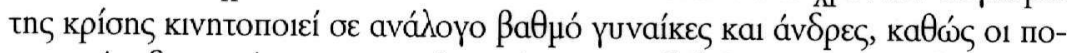

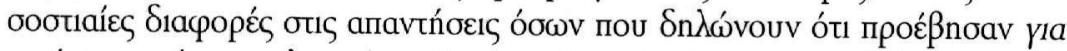

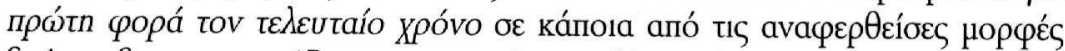

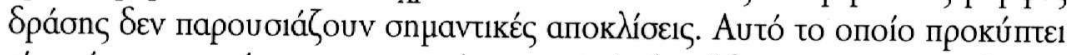

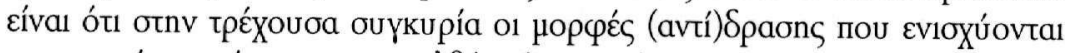

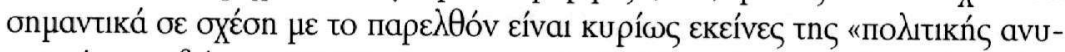

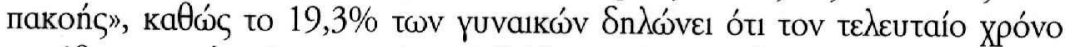

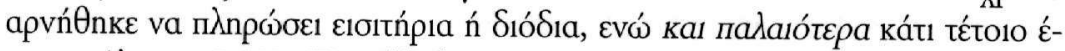

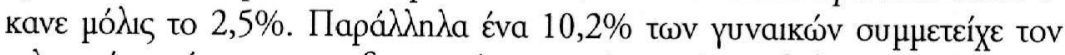

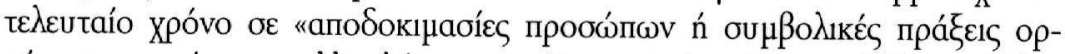

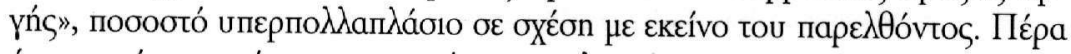

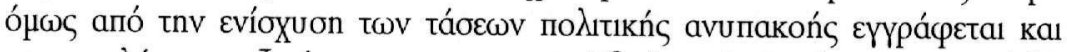

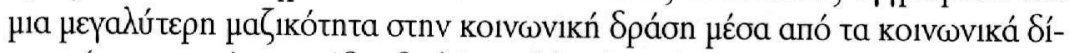

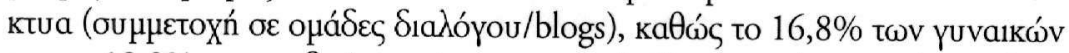

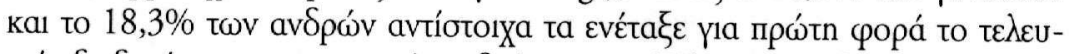

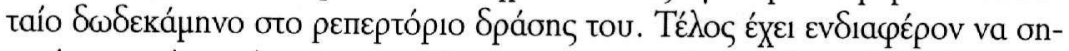

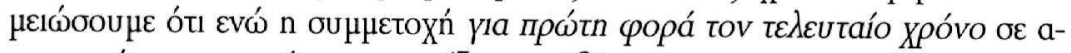

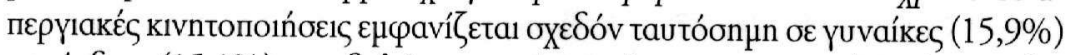

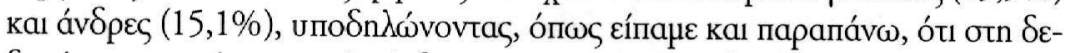

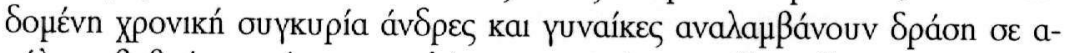

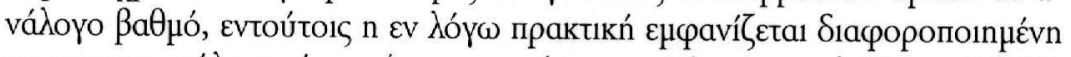

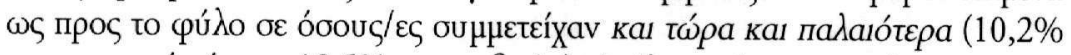

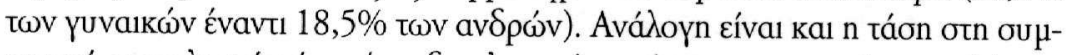

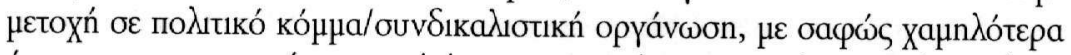

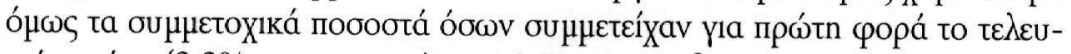

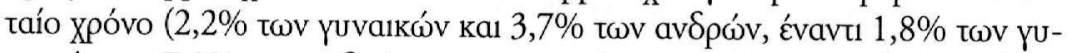

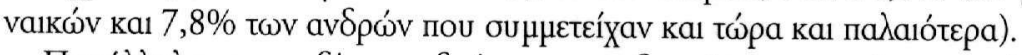

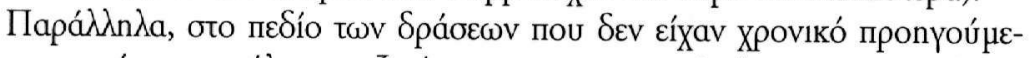

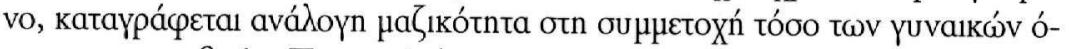

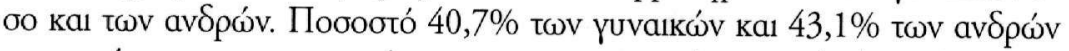

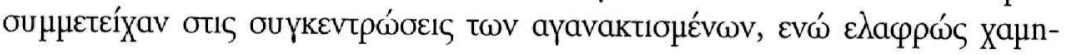

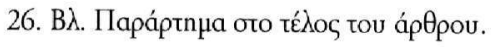




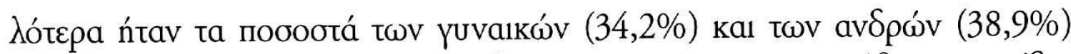

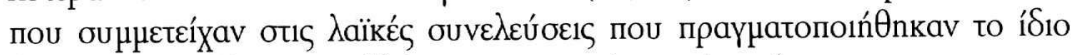

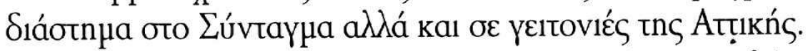

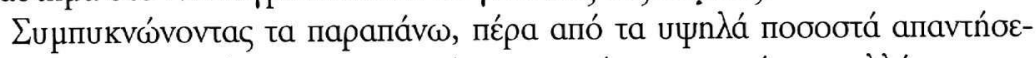

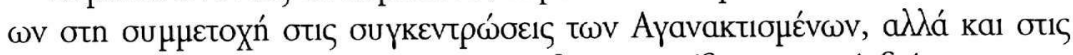

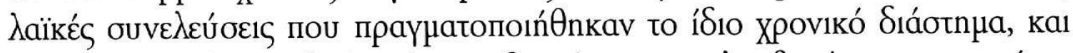

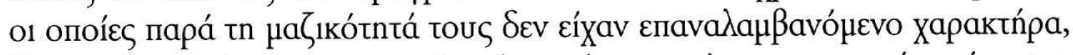

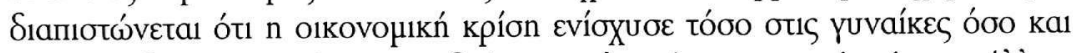

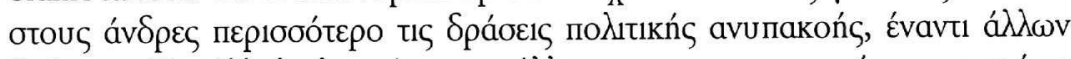

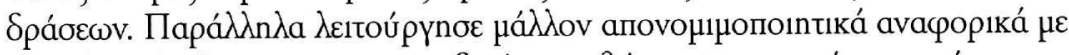

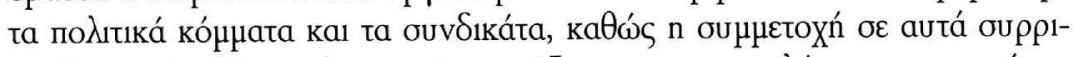

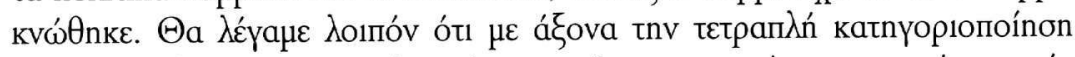

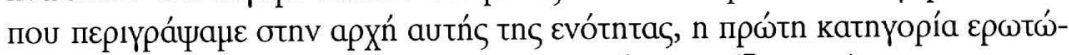

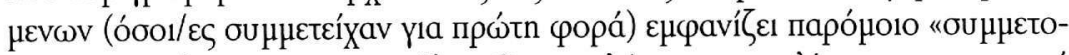

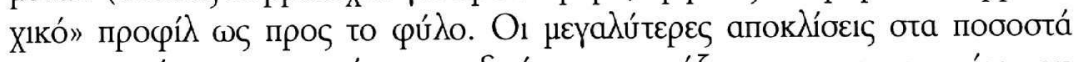

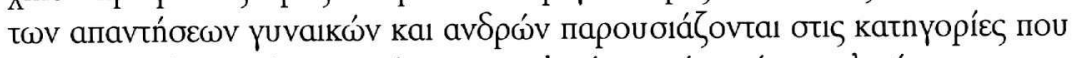

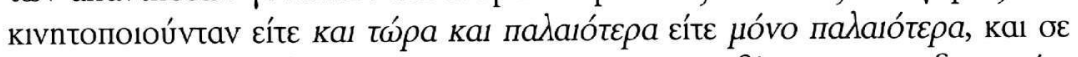

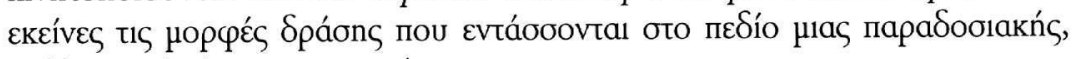

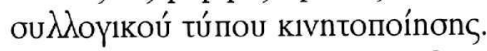

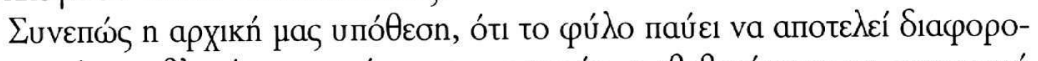

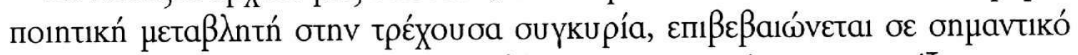

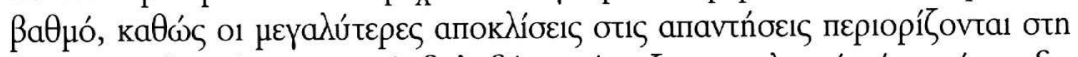

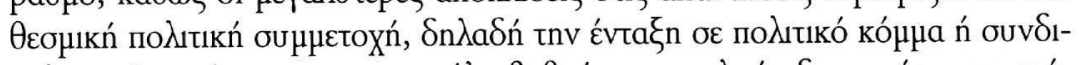

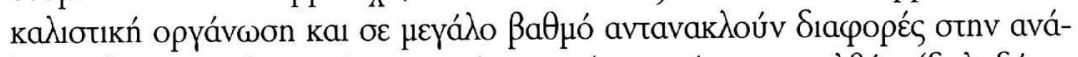

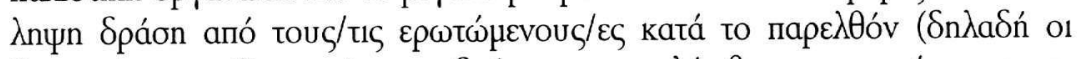

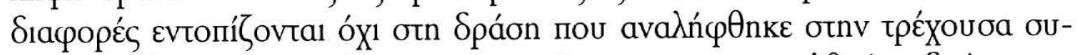

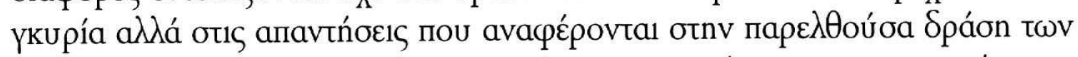

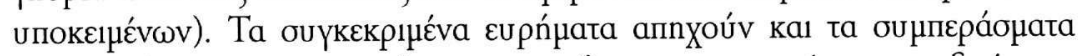

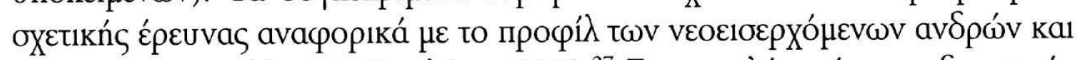

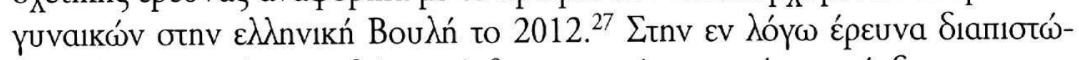

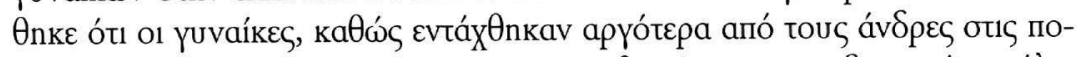

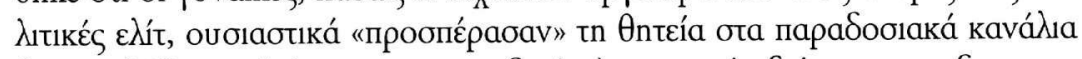

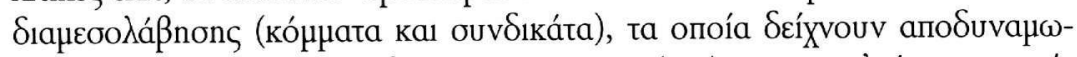

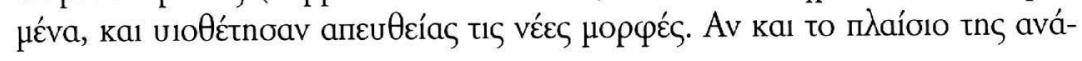

27. Bג. M. Kakepaki - Y. Karayiannis, «"The more they change, the more they stay the same?" The gendered aspect of political representation in Greece during the crisis», avakoiv $\omega$ on oro 3rd European Conference on Politics and Gender, Bapkèívn, 21-23 Maptíou 2013. 


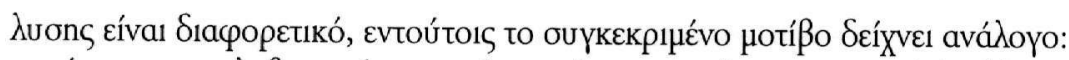

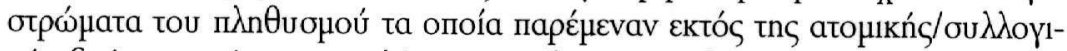

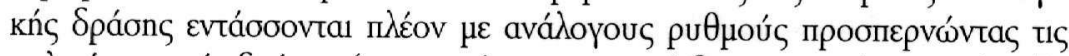

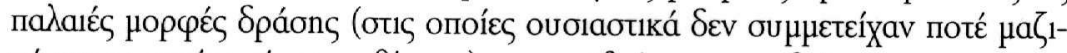

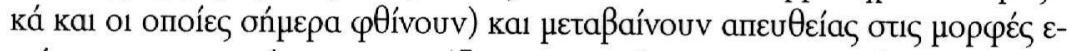

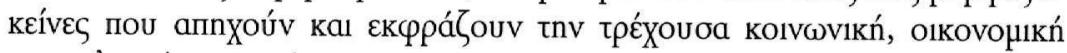
каı подıтікń бuүкupía.

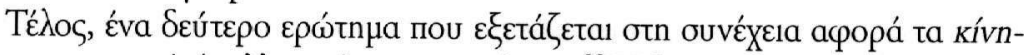

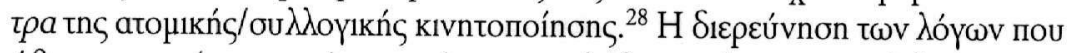

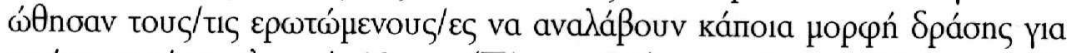

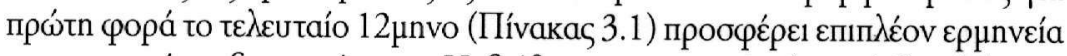

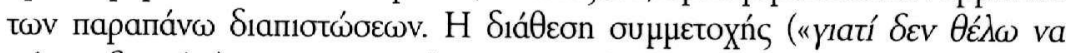

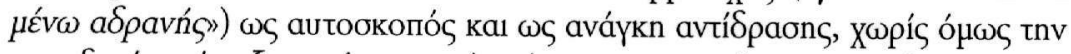

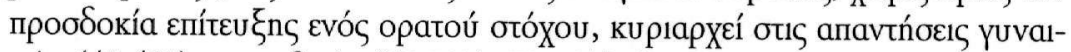

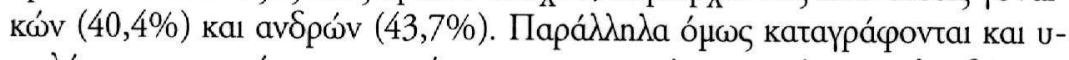

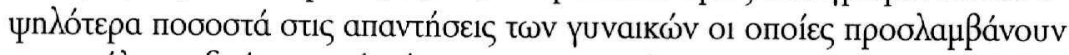

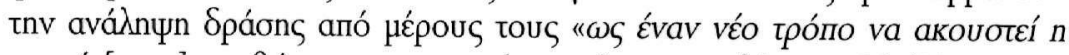

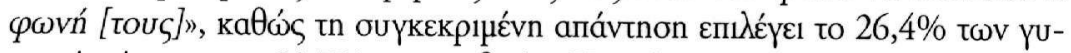

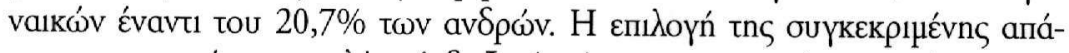

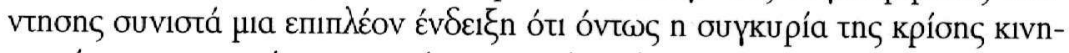

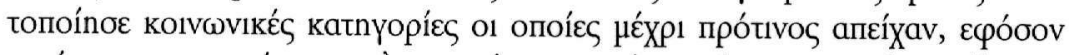

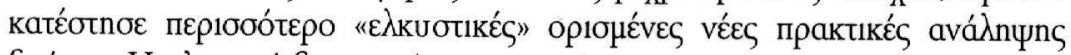

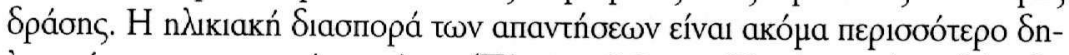

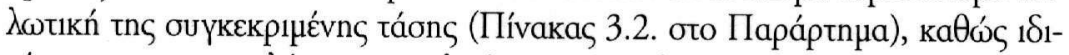

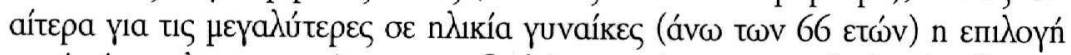

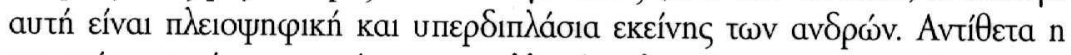

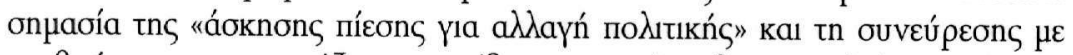

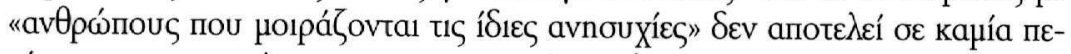

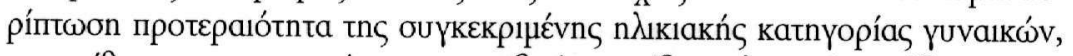

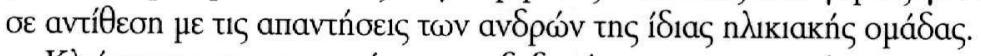

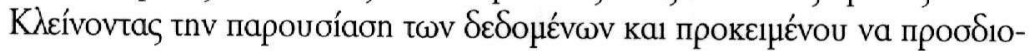

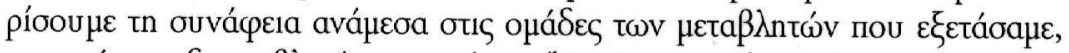

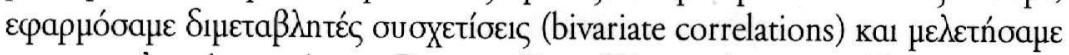

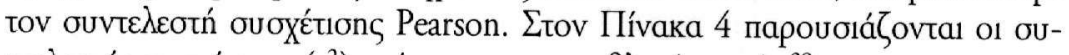

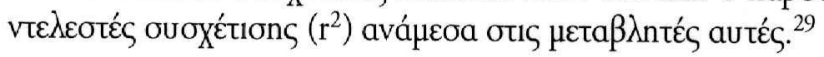

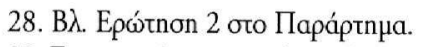

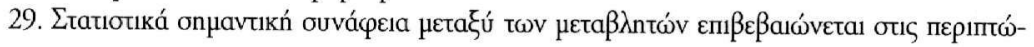




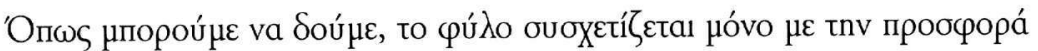

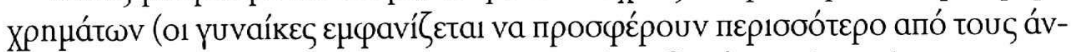

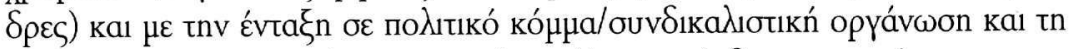

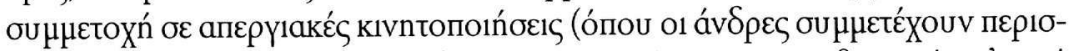

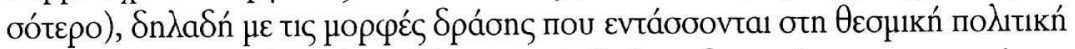

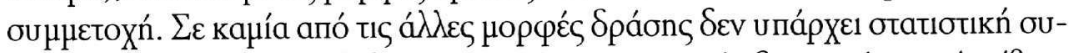

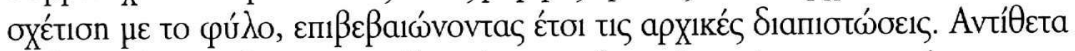

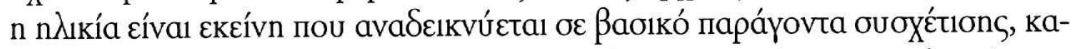

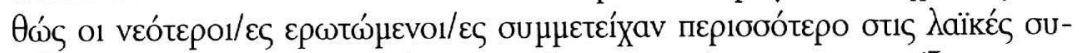

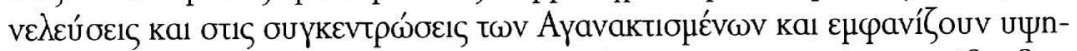

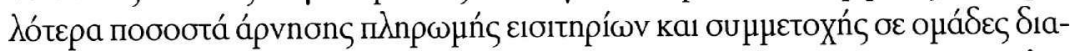

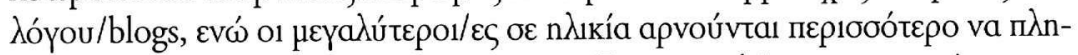

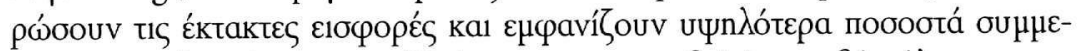

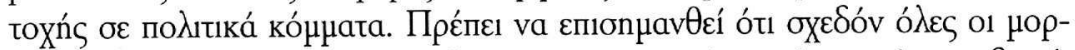

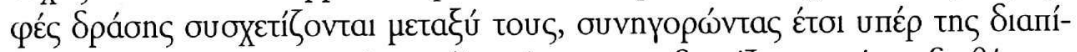

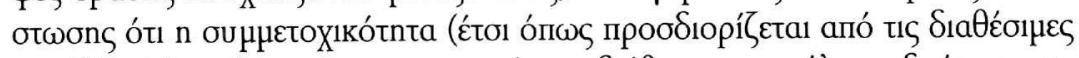

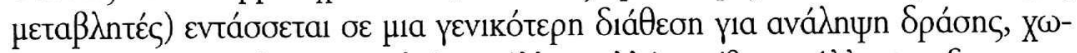

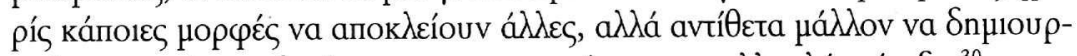

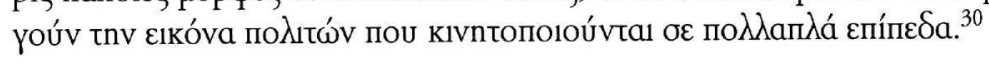

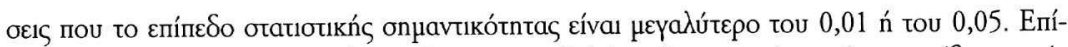

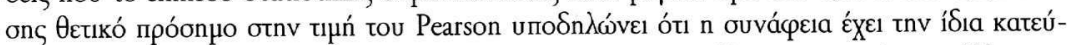

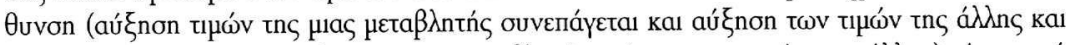

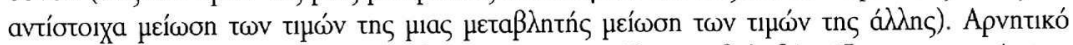

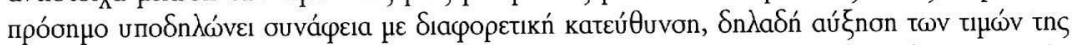

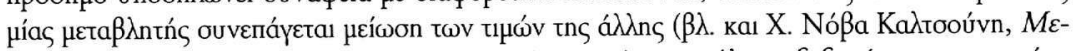

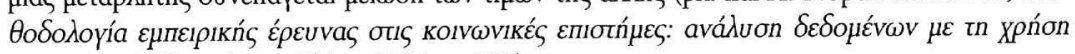
tou SPSS 13, Gutenberg, A日ńva 2006, б. 231).

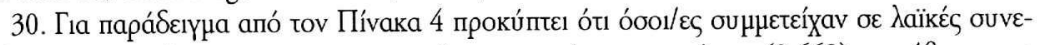

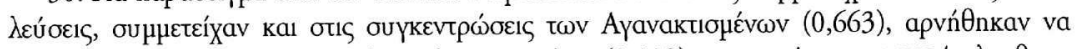

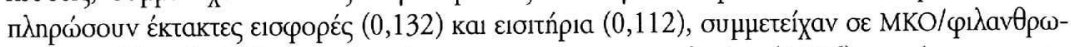

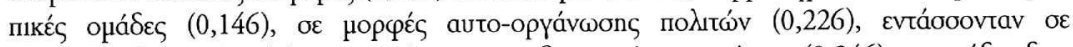

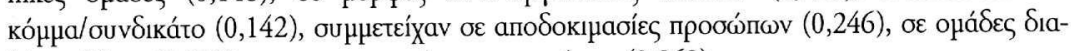

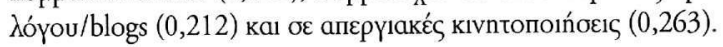




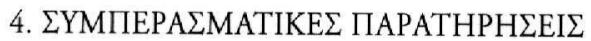

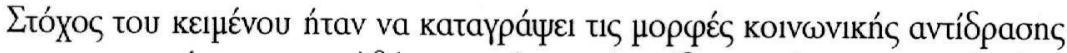

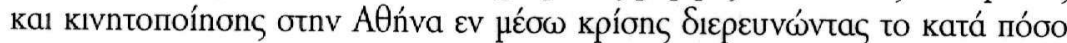

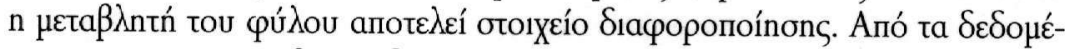

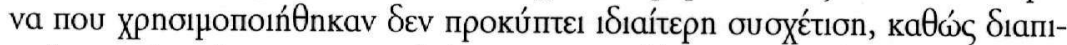

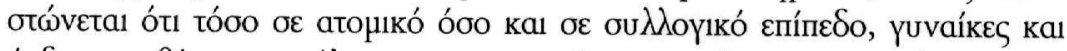

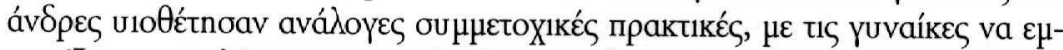

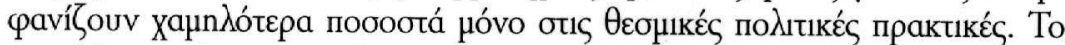

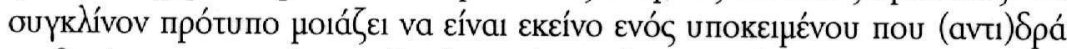

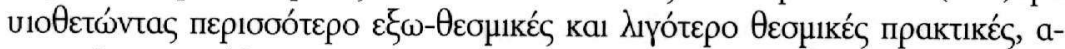

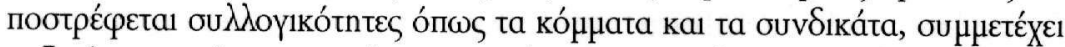

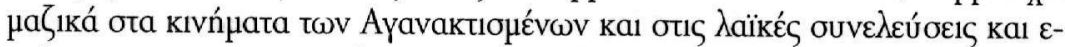

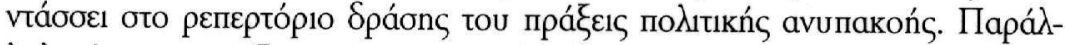

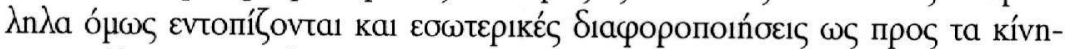

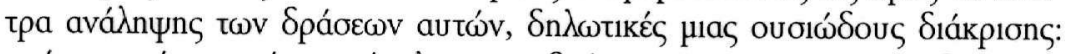

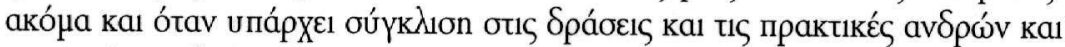

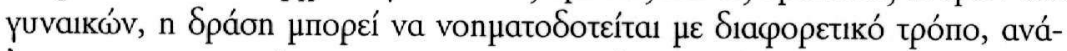

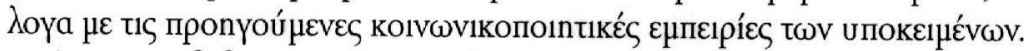

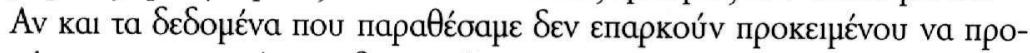

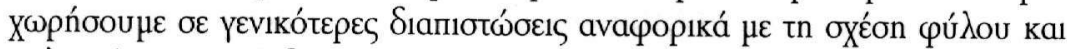

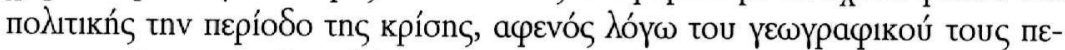

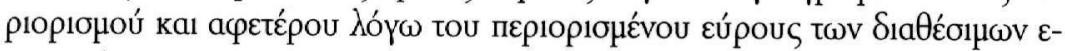

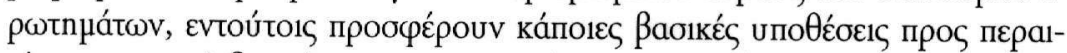

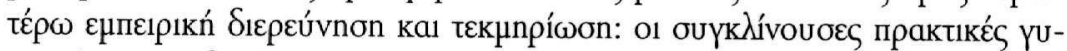

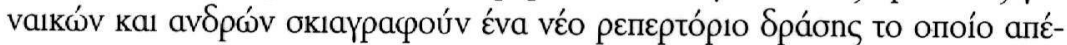

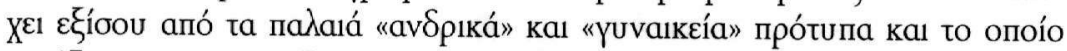

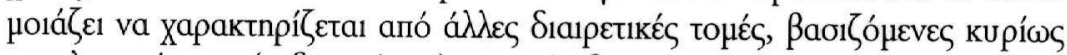

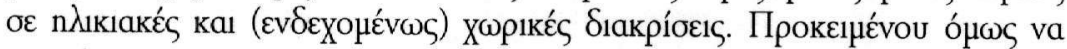

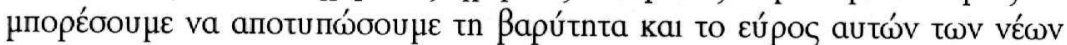

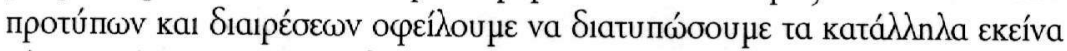

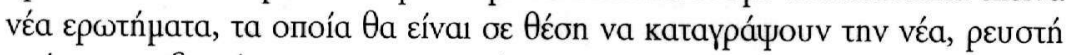

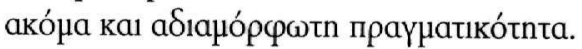




\section{ПАРАРТНМА}

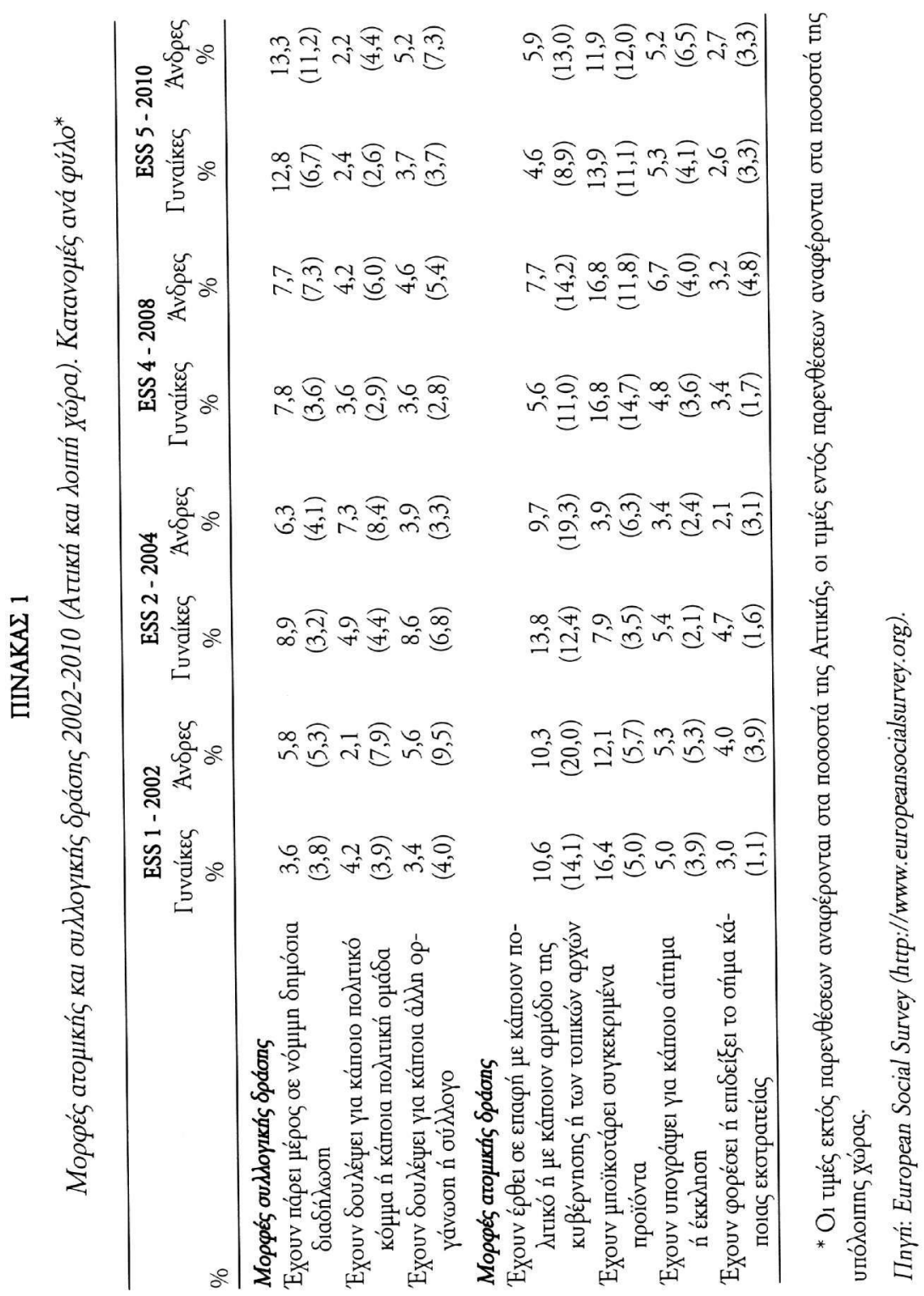




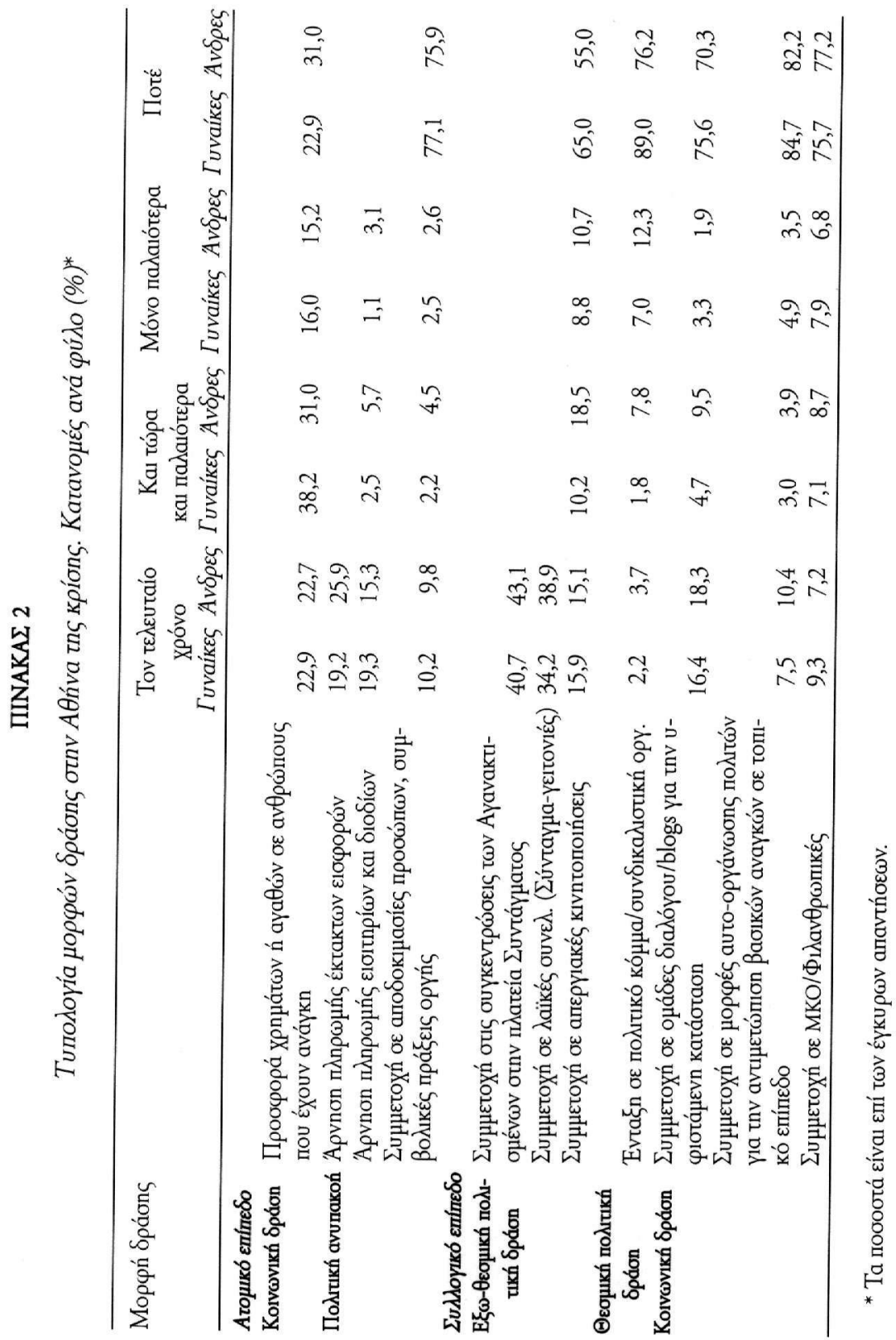




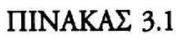

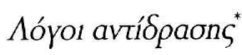

\begin{tabular}{|c|c|c|}
\hline & $\begin{array}{c}\text { Гuvaíkes } \\
\%\end{array}$ & $\begin{array}{c}\text { Avdpes } \\
\%\end{array}$ \\
\hline 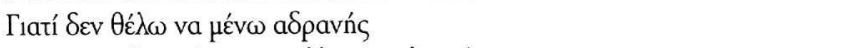 & 40,4 & 43,7 \\
\hline 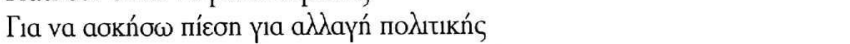 & 34,0 & 33,0 \\
\hline 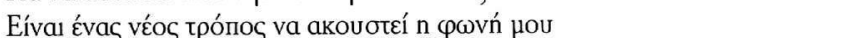 & 26,4 & 20,7 \\
\hline 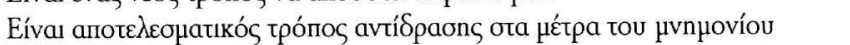 & 16,6 & 16,5 \\
\hline 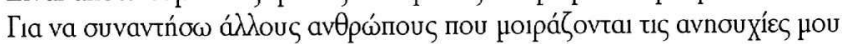 & 10,2 & 14,2 \\
\hline 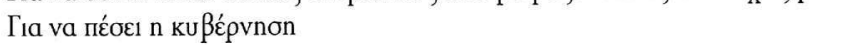 & 8,3 & 13,0 \\
\hline 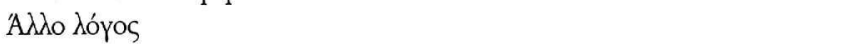 & 7,9 & 5,7 \\
\hline Апо́ перı́́рүєıа & 2,6 & 3,1 \\
\hline
\end{tabular}

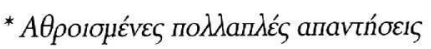

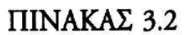

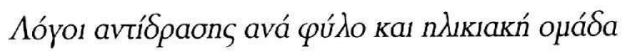

\begin{tabular}{|c|c|c|c|c|c|c|c|}
\hline Гuvaíkes & Avopes & Гuvaíkec & 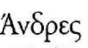 & Гuvaíkec & Avopes & Гuvaíkec & 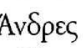 \\
\hline $15-29$ & $15-29$ & $30-49$ & $30-49$ & $50-65$ & $50-65$ & $66+$ & $66+$ \\
\hline 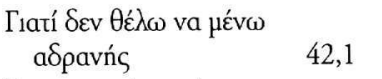 & 44,1 & 43,9 & 46,2 & 37,3 & 41,2 & 26,1 & 35,7 \\
\hline \multicolumn{6}{|l|}{ 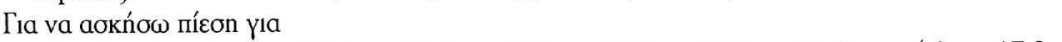 } & 4,3 & 17,9 \\
\hline 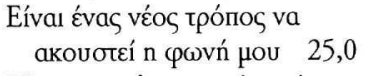 & 18,6 & 27,6 & 29,7 & 23,7 & 17,6 & 26,1 & 10,7 \\
\hline 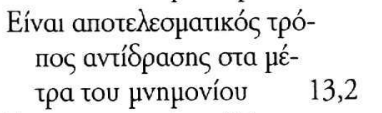 & 13,6 & 15,3 & 14,3 & 22,0 & 22,1 & 17,4 & 21,4 \\
\hline 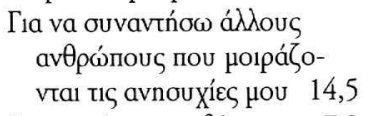 & 11,9 & 8,2 & 15,4 & 10,2 & 16,2 & 4,3 & 17,9 \\
\hline 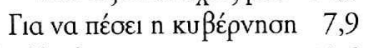 & 10,2 & 3,1 & 14,3 & 15,3 & 14,7 & 17,4 & 10,7 \\
\hline 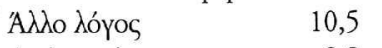 & 8,5 & 7,1 & 7,7 & 1,7 & 4,4 & 21,7 & 0,0 \\
\hline Aпó пєрıе́рүєıı & 5,1 & 4,1 & 1,1 & 0,0 & 1,5 & - 0,0 & 10,7 \\
\hline
\end{tabular}




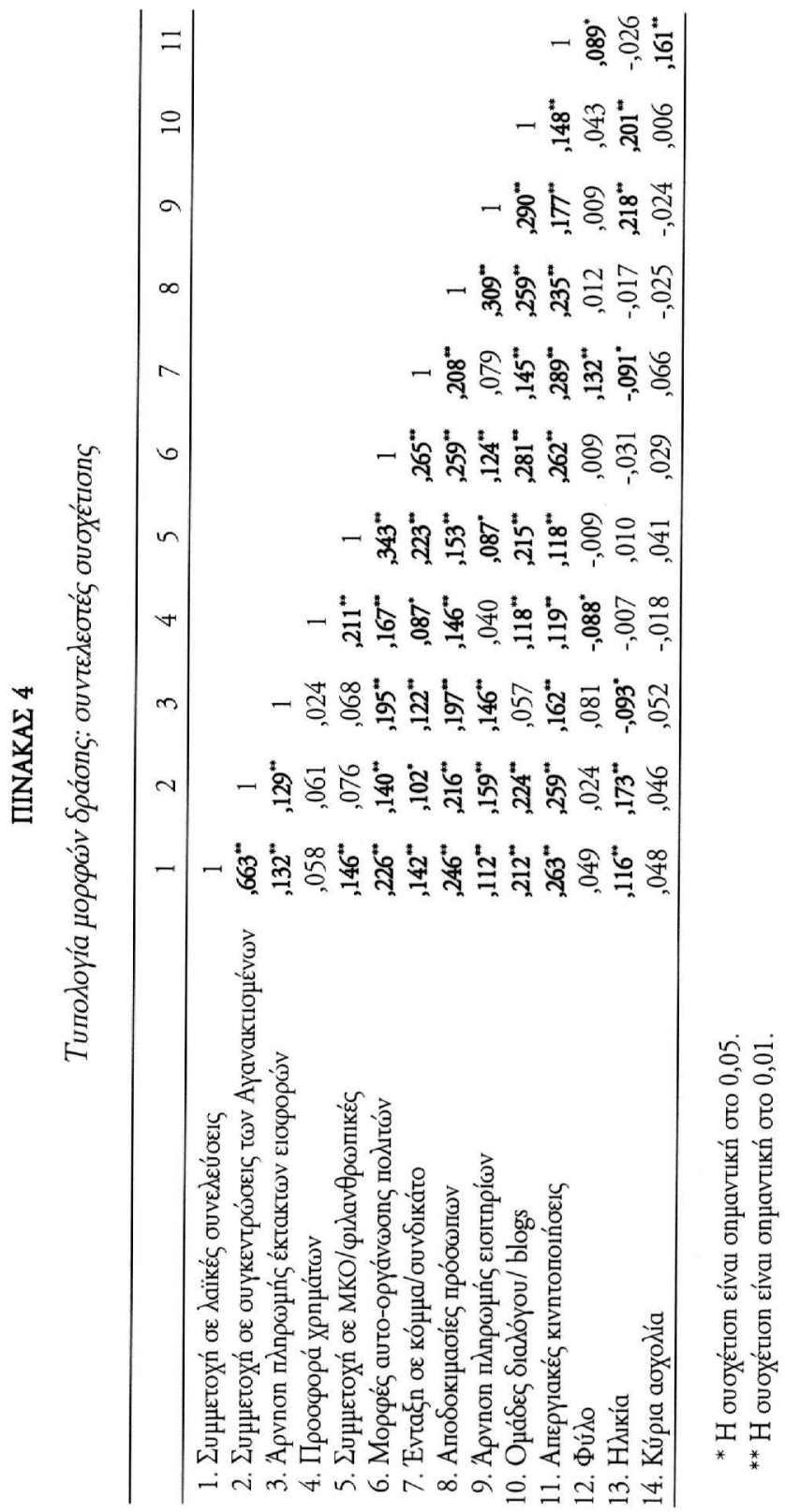




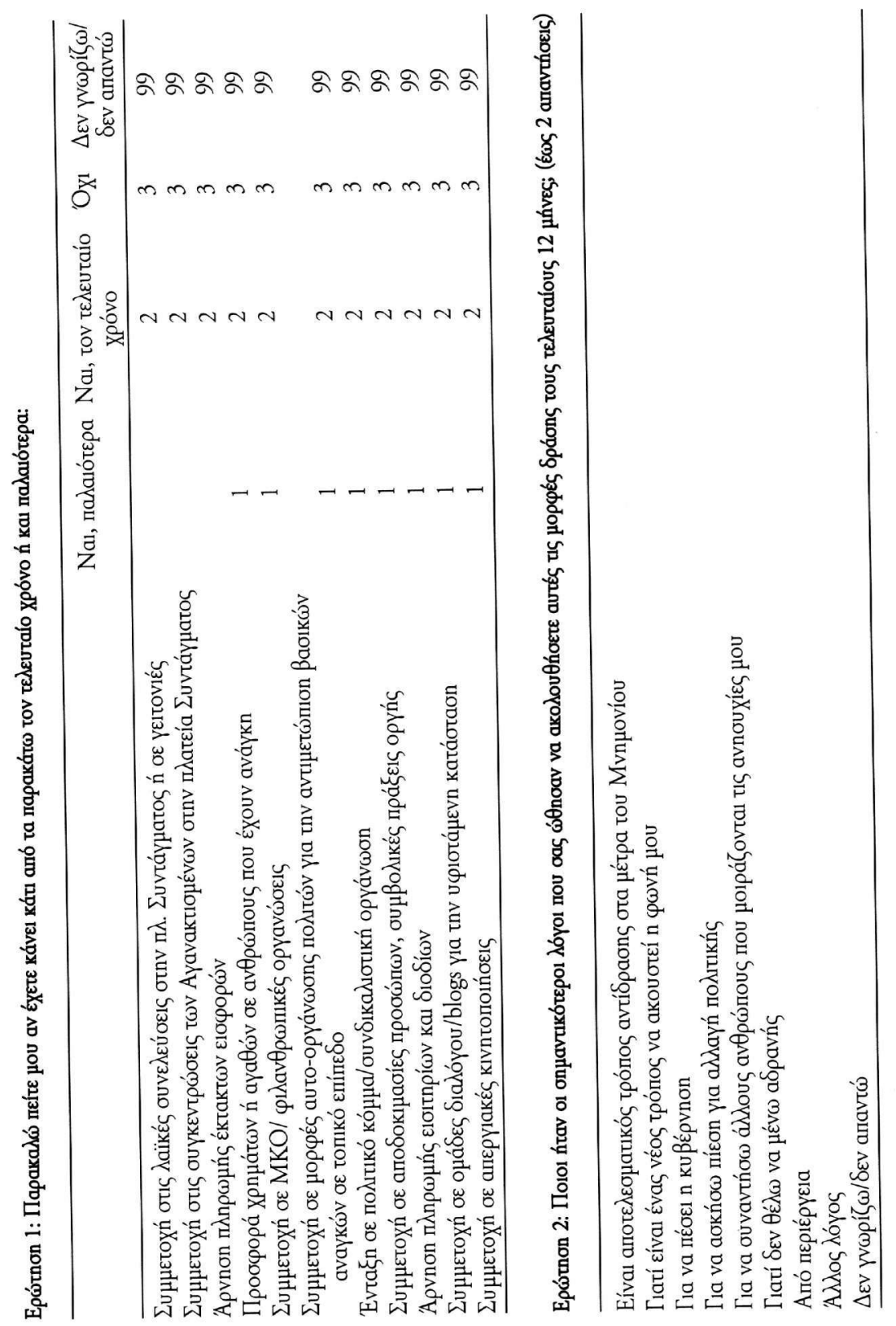

